\title{
PENGARUH BAURAN PEMASARAN \\ TERHADAP KEPUTUSAN KONSUMEN MENGINAP (Survey Pada Garden Permata Hotel Bandung)
}

\author{
Rieke Sri Rizki Asti Karini \\ Manajemen Pariwisata \\ STIEPAR YAPARI AKTRIPA BANDUNG
}

\begin{abstract}
ABSTRAK
Penelitian ini bermaksud untuk menunjukkan pengaruh tentang bauran pemasaran (yang dilakukan oleh bagian penjualan dan pemasaran Garden Permata Hotel Bandung secara bersama-sama dan individual terhadap keputusan konsumen menginap.

Penelitian dilakukan di Garden Permata Hotel Bandung Jawa Barat. Desain penelitian adalah metode survai dengan jenis explanatory survey. Populasi penelitian adalah konsumen yang menginap di Garden Permata Hotel Bandung Jawa Barat yang sekaligus berfungsi sebagai sampel dengan metode penarikan sampling purposive sampling. Jenis Jenis data yang digunakan dalam penelitian adalah cross-section dengan prosedur pengumpulan data melalui penyampaian kuesioner kepada konsumen yang terpilih sebagai sampel. Metode yang digunakan untuk analisis data dan pengujian hipotesis dalam penelitian adalah path analysis.

Hasil analisis data dan pengujian hipotesis menunjukkan bahwa bauran pemasaran yang terdiri dari produk, harga, tempat, promosi, orang, proses dan bukti fisik yang dilakukan oleh bagian penjualan dan pemasaran Garden Permata Hotel Bandung memiliki hubungan positif dengan keputusan konsumen menginap di Garden Permata Hotel Bandung
\end{abstract}

Kata kunci: Bauran Pemasaran, Konsumen, Keputusan Menginap Konsumen 


\title{
THE INFLUENCE OF SERVICE MARKETING MIX ON CONSUMER'S DECISION PROCESS IN SELECTING LODGING SERVICES (Survey on Garden Permata Hotel Bandung)
}

\begin{abstract}
The purpose of this research is to know the influence of marketing mix which has done by sales and marketing Garden Permata Hotel Bandung simultaneously although partially to the influence to the influence to the consumer's decision process in selecting lodging services.

The research has done on Garden Permata Hotel Bandung in West Java. Survey method with the explanatory survey type has used as the research design. For population of this research, has used all the costumers in Garden Permata Hotel Bandung in West Java. From the population has taken 100 costumers in Garden Permata Hotel Bandung and also considered as sample, which determined by purposive sampling method. Data type of this research is cross-section and data collecting procedure has done by questionnaire that was giving to the costumers, which has chosen as a sample of the research. Path analysis has used as data analysis method and also for hypothesis examination.

Data analysis result and hypothesis examination in this research shows that the marketing mix consists prduct, price, place, promotion, people, process, and physical evidence which has done by sales and marketing Garden Permata Hotel Bandung has positive influence to the influence to the consumer's decision process in selecting lodging services.
\end{abstract}

Keywords: Marketing Mix, Consumer, Consumer's Decision Process in Selecting Lodging Services

\section{PENDAHULUAN}

Pariwisata sebagai salah satu industri yang perkembangannya semakin meningkat. Industri ini telah membuka lapangan pekerjaan dan menyerap tenaga kerja sehingga diharapkan dapat mengurangi angka pengangguran di dunia, termasuk Indonesia. Hal ini dapat dilihat dari meningkatnya jumlah wisatawan dari tahun ke tahun, baik wisatawan domestik maupun wisatawan mancanegara. Ini dikarenakan banyaknya daerah tujuan wisata Indonesia yang sudah tertata baik yang dibuktikan dalam The Travel \& Tourism Competitiveness Index 2015 bahwa pariwisata Indonesia menempati peringkat 50 dunia setelah pada tahun 2013 hanya menempati posisi ke 70 dunia. Seiring perkembangan pariwisata yang semakin ketat, maka kota di Indonesia berlomba mendatangkan wisatawan ke kotanya sebanyak mungkin. 
Salah satunya adalah Kota Bandung. Kota yang dijuluki Parijs Van Java ini menyediakan berbagai destinasi wisata yang unik. Daya tarik wisata Kota Bandung yang cukup terkenal adalah bisnis kuliner, fashion, perhotelan dan tempat rekreasi alam. Hal ini ditandai dengan munculnya berbagai macam sarana dan fasilitas jasa wisata yang dapat menarik banyak wisatawan untuk berkunjung terutama sejak Tol Cipularang diresmikan.

Kegiatan pariwisata ini tentunya perlu ditunjang oleh kehadiran sektor lain sebagai pendukung. Salah satunya adalah usaha akomodasi. Akomodasi merupakan tempat tinggal sementara bagi para wisatawan selama melakukan perjalanan wisatanya, maka dapat menjadi salah satu penunjang dalam kegiatan wisata yang dilakukan atau para wisatawan yang melakukan perjalanan untuk mengunjungi daerah-daerah tujuan wisata, membutuhkan tempat untuk menginap, makan dan minum serta hiburan. Oleh karena itu, hotel merupakan salah satu bentuk usaha bidang jasa yang menunjang kegiatan tersebut dimana mengutamakan kualitas pelayanan bagi para tamu khususnya pelanggan.

Semakin tingginya tingkat persaingan dalam usaha jasa perhotelan yang ditandai dengan menjamurnya hotel yang menawarkan jasa dan fasilitas sejenis sehingga menuntut konsumen berfikir kritis dalam menjatuhkan pilihannya dimana mereka diharapkan mempertimbangkan untuk memilih jasa sesuai dengan harapannya, sehingga kegiatan pemasaran pada perhotelan perlu dikelola secara professional, agresif, tepat sasaran dan terpadu sesuai dengan situasi dan kondisi perusahaan..

Kini, seiring dengan perubahan yang terjadi begitu cepat dimana Kota Bandung sudah sangat ramai dan memiliki tingkat persaingan yang cukup ketat. Di kota ini terdapat berbagai macam jenis hotel yang menyediakan fasilitas lengkap, diantaranya hotel bintang 4. Berikut ini daftar hotel bintang 4 di Kota Bandung.

\begin{tabular}{|l|l|l|}
\hline No & \multicolumn{1}{|c|}{ Nama Hotel } & \multicolumn{1}{c|}{ Alamat } \\
\hline 1. & Arion Swiss Belhotel & Jl. Oto Iskandardinata 16 \\
\hline 2. & $\begin{array}{l}\text { Aston Braga Hotel \& Residence } \\
\text { Bandung }\end{array}$ & Jl. Braga No. 99 - 101 \\
\hline 3. & $\begin{array}{l}\text { Aston Primera Pasteur Hotel \& } \\
\text { Confrence Center }\end{array}$ & Jl. Dr. Djunjunan No.96 \\
\hline 4. & Carcadine & Jl. Kebon Jati No. 71-75 \\
\hline 5. & Galeri Ciumbuleuit & Jl. Cimbuleuit No. 42A \\
\hline 6. & Garden Permata Hotel & $\begin{array}{l}\text { Jl. Lembah Neundeut No 7 } \\
\text { Setrasari }\end{array}$ \\
\hline 7. & Golden Flower & Jl. Asia Afrika No. 15-17 \\
\hline 8. & Grand Pasundan Conv & $\begin{array}{l}\text { Jl. Peta No. 147 - 149 Lingkar } \\
\text { Selatan }\end{array}$ \\
\hline 9. & Grand Seriti & Jl. Hegarmanah No. 9 - 15 \\
\hline 10. & Grand Setiabudhi & Jl. Dr. Setiabudhi No. 130 - 134 \\
\hline
\end{tabular}




\begin{tabular}{|c|l|l|}
\hline 11. & $\begin{array}{l}\text { HARRIS Hotel \& Conventions } \\
\text { Festival CityLink }\end{array}$ & Jl. Peta No. 241 Kopo \\
\hline 12. & Holiday Inn & Jl. Ir . H Juanda No. 31 \\
\hline 13. & Horison & Jl. Pelajar Pejuang 45 No. 121 \\
\hline 14. & Ibis & Jl. Gatot Subroto No. 289 \\
\hline 15. & Jayakarta & Jl. Ir . H Juanda No. 381 \\
\hline 16. & Novotel Bandung & Jl. Cimbuleuit No. 23 - 25 \\
\hline 17. & Savoy Homan & Jl. Asia Afrika No. 112 \\
\hline 18. & Sensa & Jl. Cimbuleuit No. 160 \\
\hline 19. & The Amaroossa & Jl. Aceh No. 71A \\
\hline 20. & The Ardjuna Boutique & Jl. Cimbuleuit No. 152 \\
\hline 21. & The Majesty Hotel \& Apartment & Jl. Dr. Setiabudhi No. 130 - 134 \\
\hline 22. & Tropicana Hotel & Jl. Cimbuleuit No. 125 \\
\hline
\end{tabular}

Sumber : (PHRI,2015)

Dilihat dari ke 22 hotel bintang 4 Kota Bandung, hampir seluruhnya berada di lokasi strategis untuk menarik konsumen. Namun, Garden Permata Hotel Bandung memiliki beberapa keunikan dan keunggulan tersendiri dibandingkan dengan hotel lainnya. Selain karena letaknya dekat dengan pintu tol Pasteur Kota Bandung, Garden Permata Hotel Bandung menawarkan panorama dan view kota Bandung yang indah. Lokasi tersebut sangat menguntungkan karena hotel tersebut memiliki jalan akses menuju pusat perbelanjaan. Adapun tingkat occoupancy dari tahun ke tahun yang secara rinci ditunjukkan pada tabel berikut:

\begin{tabular}{|c|c|c|c|c|c|c|}
\hline & \multicolumn{2}{|c|}{2012 (YTD ) } & \multicolumn{2}{c|}{2013 (YTD ) } & \multicolumn{2}{c|}{ 2014 (YTD ) } \\
\hline & Budget & Actual & Budget & Actual & Budget & Actual \\
\hline Room & & & & & & \\
\hline $\begin{array}{c}\text { Room } \\
\text { available }\end{array}$ & 56.730 & 57.484 & 63.304 & 63.304 & 57.945 & 58.708 \\
\hline Room Sold & 35.091 & 35.420 & 41.630 & 38.348 & 38.663 & 32.896 \\
\hline $\begin{array}{c}\text { \% } \\
\text { Occupancy }\end{array}$ & $61,68 \%$ & $61,62 \%$ & $65,55 \%$ & $60,58 \%$ & $66,72 \%$ & $56,35 \%$ \\
\hline $\begin{array}{c}\text { Average } \\
\text { Room Rate }\end{array}$ & 445.042 & 414.855 & 424.271 & 463.236 & 515.770 & 470.359 \\
\hline $\begin{array}{c}\text { Room } \\
\text { Revenue }\end{array}$ & 15.616 .9 & 14.694 .1 & 17.662 .3 & 17.764 .1 & 19.941 .1 & 15.474 .7 \\
8.410 & 79.600 & 92.001 & 84.797 & 99.203 & 87.728 \\
\hline
\end{tabular}

Sumber : Annual Report Garden Permata Hotel Tahun 2012, 2013 dan 2014 (diolah kembali)

Dari tabel menunjukan bahwa tingkat occupancy Garden Permata Hotel Bandung dapat dikatakan fluktuatif dimana tiap tahunnya terjadi kenaikan dan penurunan. Hal ini tentu saja dapat menjadi suatu masalah bagi pihak hotel karena dapat mengancam pendapatan. Apalagi pada awal tahun 2014 occupancy Garden 
Permata Hotel Bandung mengalami penurunan dikarenakan pada pada bulan Januari s/d Mei dilakukan renovasi kamar dan pada akhir tahun adanya kebijakan pemerintah yang melarang penggunaan hotel bagi instansi pemerintahan menyelenggarakan rapat, seminar dll. Hal ini berkaitan dengan segmen target Garden Permata Hotel Bandung yang sebagian besar dari Government (70\%), Corporate $(15 \%)$ dan Individual $(10 \%)$ dan Other $(5 \%)$. Sehingga mengakibatkan penurunan pendapatan bagi Garden Permata Hotel Bandung

Garden Permata Hotel Bandung berusaha seoptimal mungkin untuk memberikan layanan terbaiknya dengan mempertimbangkan segala komponen dari bauran pemasaran jasa (marketing mix) yang dimilikinya sesuai kebutuhan dan keinginan konsumennya. Kegiatan pemasaran merupakan salah satu ujung tombak untuk meningkatkan penjualan yang pada akhirnya dapat meningkatnya penjualan jasa kamar. Ini tergantung pada bauran pemasaran yang dilakukannya dapat menimbulkan umpan balik bagi perusahaan. Selain itu, diperlukan kemampuan manajemen perusahaan dalam memanfaatkan peluang yang terdapat di masyarakat dan mengelola bauran pemasaran yang ada. Menurut Fandy Tjiptono (2012: 18) bahwa: "bauran pemasaran jasa adalah terdiri dari place (lokasi), price (harga), promotion (promosi), people (orang yang terkait dengan pelayanan), physical evidence (bukti fisik), dan process (proses jasa)". Hal tersebut diperkuat dengan penyataan Zeithaml, Bitner \& Gremler, Lovelock \& Wirtz dalam Oesman (2010:23), bahwa:
"Dalam perusahaan jasa penerapan bauran pemasaran perlu ditambahkan variabel-variabel yang merupakan pengembangan dari konsep bauran pemasaran jasa, yaitu orang (people), proses (process), dan bukti fisik (physical evidence). Sehingga ada tujuh bauran pemasaran untuk jasa, menjadi: produk (product), harga (price), tempat (place), promosi (promotion), proses (process), orang (people) dan bukti fisik (physical evidence), (7P) untuk mencapai tujuan perusahaan penyedia jasa"

Dari pengertian diatas dapat disimpulkan bahwa bauran pemasaran merupakan unsur pemasaran yang saling terkait dan dipadukan untuk mencapai tujuan yang diinginkan perusahaan. Bauran pemasaran jasa menjadi kunci keberhasilan dalam memenangkan persaingan dan semua itu disusun sesuai dengan kebutuhan dan keinginan konsumen yang ada. Kebutuhan pengetahuan terhadap faktor-faktor bauran pemasaran sangat dibutuhkan karena dengan strategi bauran pemasaran yang jitu, perusahaan dapat mencapai tujuannya. Pada proses pencapaian kepuasan pelanggan dapat diciptakan dengan bauran pemasaran (marketing mix) yang dapat menanggulangi gap kualitas jasa antara permintaan pasar dan penawaran perusahaan. Pentingnya proses penetapan bauran pemasaran oleh perusahaan ini akan terlihat dari besarnya pengaruh hubungan langsung antara komponen-komponen dalam bauran 
pemasaran dengan perilaku konsumen khususnya dalam mendukung keputusan pembelian.

Konsumen saat ini tidak hanya memandang produk dari manfaat inti yang ditawarkan guna memenuhi kebutuhan mereka, tapi mereka akan lebih melihat produk seperti apa yang diinginkannya. Seperti halnya pada hirarki nilai pelanggan (Fandy Tjiptono, 2012:21), "konsumen lebih melihat apa yang perusahaan tambahkan pada manfaat inti atas produk yang mereka beli dari perusahaan satu dibanding dengan apa yang ditawarkan oleh perusahaan lain". Dalam hal ini atribut pendukung manfaat inti yang ditawarkan antara perusahaan satu dengan yang lainnya berbedabeda. Maka disinilah pentingnya bagaimana suatu perusahaan menciptakan suatu produk yang sesuai dengan kebutuhan dan keinginan konsumen. Karena dengan terpenuhnya kebutuhan dan keinginan konsumen akan berdampak pada keputusan konsumen menginap yang pada akhirnya pada pembelian ulang dan terciptanya loyalitas pelanggan, serta membentuk suatu rekomendasi dari mulut ke mulut (word of mouth) yang menguntungkan bagi perusahaan. Untuk mewujudkannya, penerapan bauran pemasaran (marketing mix) sangat penting dilakukan perusahaan dengan harapan akan dapat meningkatkan volume penggunaan keputusan konsumen menginap. Seperti yang dilakukan Garden Permata Hotel Bandung untuk menarik pelanggannya. Yaitu dengan promosi outdoor (dengan adanya billboard, spanduk, promosi di media cetak, elektronik, medsos, website) dan indoor (renovasi kamar sehingga kamar yang ditawarkan menjadi lebih nyaman). Selain itu, adanya telemarketing, sales trip dan sales bliz, pemberian diskon, discount event dan berbagai cara pembayaranpun ditawarkan mudah sehingga menarik para calon pelanggan agar menginap di hotel Garden Permata Hotel Bandung.

Konsumsi jasa digunakan dalam tiga tahap yaitu tahap sebelum pembelian, pertemuan jasa dan paska pertemuan jasa. Dari tahapan tersebut, konsumen membuat keputusan penggunaan pada tahap prepurchase. Hal ini sejalan dengan pernyataan Lovelock \& Wirtz (2011:58-59) bahwa "service consumption can be divided into three principal stages: prepurchase, service encounter and postencounter." Selanjutnya, Kotler dan Amstrong (2008:101) menyatakan bahwa "pada kebanyakan orang, perilaku pembelian konsumen seringkali diawali dan dipengaruhi oleh banyaknya rangsangan (stimuli) dari luar dirinya, baik berupa rangsangan pemasaran maupun rangsangan dari lingkungan yang lain". Lebih lanjut Kotler dan Armstrong (2008:196) menyatakan: "dalam model customer blackbox proses, keputusan penggunaan konsumen dipengaruhi oleh stimulus bauran pemasaran.

Berdasarkan pada berbagai fenomena dan pemikiran yang telah dikemukakan di muka, maka penulis berkeinginan untuk melaksanakan penelitian mengenai "Pengaruh bauran pemasaran (marketing mix) terhadap keputusan konsumen menginap (Survei pada Garden Permata Hotel Bandung)". Adapun identifikasi masalah penelitian ini adalah:

1. Apakah bauran pemasaran (marketing mix) yang meliputi produk (product), harga (price), tempat (place), promosi (promotion), proses (process), orang (people) 
dan bukti fisik (physical evidence) secara simultan berpengaruh terhadap keputusan konsumen menginap

2. Apakah bauran pemasaran (marketing mix) yang meliputi produk (product), harga (price), tempat (place), promosi (promotion), proses (process), orang (people) dan bukti fisik (physical evidence) secara parsial berpengaruh terhadap keputusan konsumen menginap

\section{METODE PENELITIAN}

Objek penelitian ini terdiri dari dua variabel, yaitu variabel independen/ bebas dan variabel dependen/ terikat. Variabel independen/ bebasnya adalah bauran pemasaran (marketing mix) $(\mathbf{X})$, meliputi product $\left(\mathbf{X}_{\mathbf{1}}\right)$, Price $\left(\mathbf{X}_{2}\right)$, Place $\left(\mathbf{X}_{\mathbf{3}}\right)$, Promotion $\left(\mathbf{X}_{\mathbf{4}}\right)$, People $\left(\mathbf{X}_{5}\right)$, Process $\left(\mathbf{X}_{\mathbf{6}}\right)$, dan Phycical Evedence $\left(\mathbf{X}_{\mathbf{7}}\right)$. Adapun variabel dependen/ terikatnya keputusan konsumen menginap $(\mathbf{Y})$.

Desain penelitian penelitian ini adalah metode penelitian survai dengan jenis penelitian explanatory survey. Adapun populasinya semua konsumen individu hotel yang menginap di Garden Permata Hotel Bandung. Setiap anggota populasi mempunyai peluang yang sama untuk dijadikan sebagai sampel, karena semuanya bersifat homogen. Sifat acak atau random dari responden diasumsikan telah terwakili melalui sifat acak dari pengembalian kuesioner, sehingga seluruh responden yang mengembalikan kuesioner dianggap membentuk sampel dari populasi yang ingin diteliti. Adapun jumlah keseluruhan tamu individu dimana menjadi populasi pada penelitian ini sebanyak 44.403 tamu berdasarkan data yang didapat dari Sales \& Marketing Garden Permata Hotel Bandung.

Metode penarikan sampel yang digunakan dalam penelitian ini adalah purposive sampling. Banyaknya sampel minimum yang akan diambil dari populasi dalam penelitian ini ditentukan dengan menggunakan rumus Slovin dengan tingkat signifikansi sebesar 10\%, sehingga jumlah sampel minimum yang diteliti yaitu sebesar 100 responden. tamu yang menginap di Garden Permata Hotel Bandung.

Jenis data yang digunakan dalam penelitian ini adalah data cross-section, dengan sumber data utamanya adalah data primer yang diperoleh melalui teknik penyebaran kuesioner, wawancara dan observasi. Sementara itu, untuk melengkapinya dibutuhkan data penunjang dalam bentuk data sekunder yang diperoleh melalui teknik dokumentasi data-data yang diperlukan.

Indikator-indikator dalam penelitian ini berskala ordinal yang diukur berdasarkan teknik skala Likert. Adapun metode pengujian datanya meliputi:

a. Uji Kesakhihan (test of validity)

Menggunakan Teknik Korelasi Product Moment dari Pearson. Berdasarkan pada teknik tersebut, maka dapat diketahui nilai validitas (r) yang menunjukkan datadata yang termasuk dalam kategori positif/ valid dan negatif/ tidak valid.

b. Uji Keandalan (test of reliability)

Menggunakan teknik uji belah dua (split-half). Berdasarkan pada Teknik Korelasi

Reliabilitas Spearman Brown, maka dapat diketahui nilai reliabilitas $\left(\mathrm{r}_{\mathrm{tot}}\right)$ yang 
menunjukkan keseluruhan item pertanyaan yang diuji termasuk dalam kategori positif/ reliabel dan negatif/ tidak reliabel.

Metode yang digunakan untuk menganalisis data-data dalam penelitian ini adalah analisis jalur (path analysis). Analisis jalur ini menganalisis mengenai hubungan kausal dengan tujuan memisahkan pengaruh langsung dan pengaruh tidak langsung suatu variabel penyebab terhadap variabel akibat (Kerlinger, 1973:305). Sehubungan dengan tingkat pengukuran untuk variabel $\mathrm{X}$ dan variabel $\mathrm{Y}$ dalam penelitian ini berskala ordinal, maka harus ditingkatkan menjadi skala interval melalui metode interval berurutan atau method of successive intervals. (Hay's, 1969:39)

Berdasarkan identifikasi masalah dalam penelitian ini, maka rancangan hipotesis statistik yang akan diuji sebagai berikut:

\section{Hipotesis Statistik Pertama:}

$\mathrm{Ho}_{1}$ : Bauran pemasaran jasa ( marketing mix) (X), yang meliputi product, price, place, promotion, people, process, dan phycical evedence secara bersama-sama tidak berpengaruh terhadap keputusan konsumen menginap (Y)

$$
\mathrm{Ho}_{1}: \mathrm{Pyx}_{1}=\mathrm{Pyx}_{2}=\mathrm{Pyx}_{3}=\mathrm{Pyx}_{4}=\mathrm{Pyx}_{5}=\mathrm{Pyx}_{6}=\mathrm{Pyx}_{7}=0
$$

$\mathrm{Ha}_{1}$ : Bauran pemasaran jasa ( marketing mix) (X), yang meliputi product, price, place, promotion, people, process, dan phycical evedence secara bersama-sama berpengaruh terhadap keputusan konsumen menginap (Y) $\mathrm{Ha}_{1}$ : Paling sedikit ada satu $\mathrm{Pyx}_{\mathrm{i}} \neq 0$, dimana $: \mathrm{i}=1,2,3,4,5,6,7$

\section{Hipotesis Statistik Kedua:}

$\mathrm{Ho}_{2}$ : Bauran pemasaran jasa ( marketing mix) (X), yang meliputi product, price, place, promotion, people, process, dan phycical evedence secara parsial tidak berpengaruh terhadap keputusan konsumen menginap (Y) $\mathrm{Ho}_{2}: \mathrm{Pyx}_{\mathrm{i}} \leq 0$, dimana $: \mathrm{i}=1,2,3,4,5,6,7$

$\mathrm{Ha}_{2}$ : Bauran pemasaran jasa ( marketing mix) (X), yang meliputi product, price, place, promotion, people, process, dan phycical evedence secara parsial berpengaruh terhadap keputusan konsumen menginap (Y) $\mathrm{Ha}_{2}: \mathrm{Pyx}_{\mathrm{i}}>0$, dimana $\mathrm{i}=: 1,2,3,4,5,6,7$

Langkah-langkah yang dijalankan dalam mengalisis data dengan menggunakan analisis jalur disesuaikan dengan modifikasi dari Harun Al Rasjid dalam Nirwana SK Sitepu (1994:19-28). Adapun pengujian hipotesis dalam penelitian ini dilakukan dengan menggunakan dua cara yaitu:

\section{a. Pengujian secara bersama-sama}

a. Merumuskan hipotesis statistik :

Ho : $\mathrm{Pyx}_{1}=\mathrm{Pyx}_{2}=\mathrm{Pyx}_{3} \mathrm{Pyx}_{4}=\mathrm{Pyx}_{5}=\mathrm{Pyx}_{6}=\mathrm{Pyx}_{7}=0$, artinya tidak terdapat pengaruh. 
Ha : $\mathrm{Pyx}_{\mathrm{i}} \neq 0$, dimana $: \mathrm{i}=1,2,3,4,5,6,7$, artinya terdapat pengaruh atau minimal terdapat satu koefisien jalur yang berpengaruh.

b. Melakukan pengujian statistik :

Alat uji statistik yang digunakan untuk pengujian secara bersama-sama yaitu Uji-F. Besarnya nilai $F$ dihitung dengan rumus yaitu:

$$
\mathbf{F}=\frac{(\mathbf{n}-\mathbf{k}-\mathbf{1})\left\{\mathbf{R}^{2} \mathbf{y}_{\left.\left(\mathbf{x}_{1} \mathbf{x}_{2} \mathbf{x}_{3}\right)\right\}}\right.}{k\left\{1-\mathbf{R}^{2} \mathbf{y}_{\left(\mathbf{x}_{1} \mathbf{x}_{2} \mathbf{x}_{3}\right)}\right\}}
$$

c. Menentukan kriteria pengujian:

Jika $\mathrm{F}_{\text {hitung }} \leq \mathrm{F}_{\text {tabel }}: \mathrm{H}_{0}$ diterima atau $\mathrm{H}_{1}$ ditolak

Jika $\mathrm{F}_{\text {hitung }}>\mathrm{F}_{\text {tabel }}: \mathrm{H}_{1}$ diterima atau $\mathrm{H}_{0}$ ditolak

F tabel $\left\{\mathrm{F}_{\alpha, \mathrm{k},(\mathrm{n}-\mathrm{k}-1)}\right\}$ diperoleh dari tabel distribusi F-Snedecor pada taraf kesalahan $\alpha$ dan derajat bebas $\mathrm{v}_{1}=\mathrm{k} ; \mathrm{v}_{2}=\mathrm{n}-\mathrm{k}-1$.

\section{b. Pengujian secara parsial}

a. Merumuskan hipotesis statistik :

Jika hasil pengujian secara bersama-sama menolak $\mathrm{H}_{0}$, berarti sekurangkurangnya ada sebuah Pyxi $\neq 0$. Agar dapat diketahui Pyxi yang secara benar mempengaruhi variabel endogenus, maka perlu dilakukan pengujian secara parsial dengan hipotesis sebagai berikut:

Ho : $\mathrm{Pyx}_{\mathrm{i}} \leq 0$, dimana $\mathrm{i}=1,2,3,4,5,6,7$

Ha : $\mathrm{Pyx}_{\mathrm{i}}>0$, dimana $\mathrm{i}=1,2,3,4,5,6,7$

b. Melakukan pengujian statistik :

Alat uji statistik yang digunakan untuk pengujian secara parsial yaitu Uji-t. Besarnya nilai $t_{\text {hitung }}$ dihitung dengan rumus yaitu:

$$
t_{i}=\frac{\mathbf{P y x}_{\mathbf{i}}}{\sqrt{\frac{\left\{1-\mathbf{R}^{2} \mathbf{y}_{\left(\mathbf{x}_{1} \mathbf{x}_{2} \mathbf{x}_{3}\right)}\right\} \mathbf{C R}_{\mathbf{i}}}{n-k-1}}} ; i=1,2,3
$$

c. Menentukan kriteria pengujian :

Jika $t_{\text {hitung }} \leq \mathrm{t}_{\text {tabel }}: \mathrm{H}_{0}$ diterima atau $\mathrm{H}_{1}$ ditolak

Jika $t_{\text {hitung }}>\mathrm{t}_{\text {tabel }}: \mathrm{H}_{1}$ diterima atau $\mathrm{H}_{0}$ ditolak

$\mathrm{t}_{\text {tabel }}\left\{\mathrm{t}_{\alpha, \mathrm{k},(\mathrm{n}-\mathrm{k}-1)}\right.$ diperoleh dari tabel distribusi t-student pada taraf kesalahan $\alpha$ untuk satu pihak dan derajat bebas $\mathrm{v}=\mathrm{n}-\mathrm{k}-1$. 


\section{HASIL DAN PEMBAHASAN}

Penyampaian kuesioner penelitian kepada para responden dilakukan selama sekitar satu bulan yang dimulai pada awal Juli 2015 hingga awal Agustus 2015. Selama kurun waktu tersebut, peneliti memperoleh hasil jawaban pertanyaan kuesioner dari para responden yang memenuhi syarat kelengkapan data sebanyak 100 eksemplar dengan perincian sebagai berikut:

\begin{tabular}{|c|c|c|}
\hline Teknik & \multicolumn{2}{|c|}{ Jumlah Kuesioner Penelitian } \\
\cline { 2 - 3 } $\begin{array}{c}\text { Penyampaian } \\
\text { Kuesioner }\end{array}$ & Yang Disampaikan & $\begin{array}{c}\text { Yang Diterima } \\
\text { Kembali }\end{array}$ \\
\hline Secara Langsung & 85 Eksemplar & 85 Eksemplar \\
\hline $\begin{array}{c}\text { Secara Tidak } \\
\text { Langsung (via PT Pos } \\
\text { Indonesia) }\end{array}$ & 85 Eksemplar & 15 Eksemplar \\
\hline Total & 170 Eksemplar & 100 Eksemplar \\
\hline
\end{tabular}

Berdasarkan pada hasil jawaban untuk setiap item pertanyaan kuesioner penelitian tersebut, kemudian dilakukan tabulasi data dengan memberikan skor berdasarkan teknik skala Likert. Adapun hasil pengujian data yang memanfaatkan Program "Pathcel Microsoft Excel - Windows 2010" dan SPSS 20 sebagai berikut:

\section{a. Uji Validitas}

1) Uji Validitas untuk Variabel Produk ( Product $/ X_{1}$ )

Berdasarkan hasil uji validitas terhadap 14 item pertanyaan ditunjukkan:

\begin{tabular}{|c|r|r|r|r|r|r|r|}
\multicolumn{1}{c}{ No. Item } & 2 & 3 & 4 & 5 & $\mathbf{6}$ \\
\hline r & $\mathbf{0 . 4 3 5 2}$ & $\mathbf{0 . 3 6 0 9}$ & $\mathbf{- 0 . 3 5 2 1}$ & $\mathbf{0 . 4 2 3 9}$ & $\mathbf{0 . 1 4 0 5}$ & $\mathbf{0 . 2 2 5 2}$ & $\mathbf{0 . 5 0 0 8}$ \\
\hline Keputusan & positif & positif & negatif & positif & positif & positif & positif \\
\hline Kesimpulan & valid & valid & $\begin{array}{r}\text { tdk. } \\
\text { valid }\end{array}$ & valid & valid & valid & valid \\
& & & & & & \\
\hline \multicolumn{7}{|c|}{ No. Item } \\
\hline r & $\mathbf{0 . 0 6 1 2}$ & $\mathbf{0 . 2 2 0 7}$ & $\mathbf{0 . 3 6 5 7}$ & $\mathbf{0 . 4 6 7 9}$ & $\mathbf{- 0 . 0 0 6 9}$ & $\mathbf{0 . 5 8 9 9}$ & $\mathbf{0 . 5 0 0 6}$ \\
\hline Keputusan & positif & positif & positif & positif & negatif & positif & positif \\
\hline Kesimpulan & valid & valid & valid & valid & tdk. & valid & valid \\
& & & & & valid & & \\
\hline
\end{tabular}

2) Uji Validitas untuk Variabel Harga ( Price / $X_{2}$ )

Berdasarkan hasil uji validitas terhadap 24 item pertanyaan ditunjukkan: 
No. Item

\begin{tabular}{|c|r|r|r|r|r|r|r|r|}
\multicolumn{1}{c}{} & \multicolumn{2}{c}{$\mathbf{1}$} & 2 & $\mathbf{3}$ & $\mathbf{6}$ & $\mathbf{7}$ & $\mathbf{8}$ \\
\hline $\mathbf{r}$ & $\mathbf{0 . 3 3 9 4}$ & $\mathbf{0 . 7 1 7 5}$ & $\mathbf{0 . 6 2 5 1}$ & $\mathbf{0 . 7 1 1 8}$ & $\mathbf{0 . 7 2 0 4}$ & $\mathbf{0 . 1 5 8 8}$ & $\mathbf{- 0 . 0 4 0 0}$ & $\mathbf{0 . 0 0 2 7}$ \\
\hline Keputusan & positif & positif & positif & positif & positif & positif & negatif & positif \\
\hline Kesimpulan & valid & valid & valid & valid & valid & valid & $\begin{array}{r}\text { tdk. } \\
\text { valid }\end{array}$ & valid \\
\hline
\end{tabular}

\begin{tabular}{|c|c|c|c|c|c|c|c|c|}
\hline & \multicolumn{8}{|c|}{ No. Item } \\
\hline & 9 & 10 & 11 & 12 & 13 & 14 & 15 & 16 \\
\hline $\mathbf{r}$ & 0.4034 & 0.1395 & 0.5421 & -0.1743 & -0.1161 & -0.3169 & 0.6661 & 0.6182 \\
\hline Keputusan & positif & positif & positif & negatif & negatif & negati & positif & positif \\
\hline Kesimpulan & valid & valid & valid & $\begin{array}{r}\text { tdk. } \\
\text { valid }\end{array}$ & $\begin{array}{r}\text { tdk. } \\
\text { valid }\end{array}$ & $\begin{array}{r}\text { tdk. } \\
\text { valid }\end{array}$ & valid & valid \\
\hline
\end{tabular}

No.

Item

\begin{tabular}{|c|r|r|r|r|r|r|r|r|}
\multicolumn{1}{c}{} & \multicolumn{2}{c}{17} & \multicolumn{2}{c}{18} & $\mathbf{2 1}$ & 22 & 23 & $\mathbf{2 4}$ \\
\hline r & $\mathbf{0 . 1 3 4 0}$ & $\mathbf{0 . 5 3 4 2}$ & $\mathbf{0 . 3 9 0 9}$ & $\mathbf{0 . 4 3 7 8}$ & $\mathbf{- 0 . 4 9 6 1}$ & $\mathbf{- 0 . 1 0 0 6}$ & $\mathbf{0 . 0 4 4 5}$ & $\begin{array}{r}- \\
\mathbf{0 . 3 0 5 5}\end{array}$ \\
\hline Keputusan & positif & positif & positif & positif & negatif & $\begin{array}{r}\text { negati } \\
\text { f }\end{array}$ & $\begin{array}{r}\text { positif } \\
\text { negati } \\
\text { f }\end{array}$ \\
\hline Kesimpulan & valid & valid & valid & valid & $\begin{array}{r}\text { tdk. } \\
\text { valid }\end{array}$ & $\begin{array}{r}\text { tdk. } \\
\text { valid }\end{array}$ & valid & $\begin{array}{r}\text { tdk. } \\
\text { valid }\end{array}$ \\
\hline
\end{tabular}

3) Uji Validitas untuk Variabel Tempat ( Place / $\mathrm{X}_{3}$ )

Berdasarkan hasil uji validitas terhadap 16 item pertanyaan ditunjukkan:

No. Item

\begin{tabular}{|c|c|c|c|c|c|c|c|c|}
\hline & \multicolumn{8}{|c|}{ No. Item } \\
\hline & 1 & 2 & 3 & 4 & 5 & 6 & 7 & 8 \\
\hline $\mathbf{r}$ & 0.6736 & 0.8092 & 0.8135 & 0.6194 & 0.8135 & 0.1812 & 0.2101 & -0.0342 \\
\hline Keputusan & positif & positif & positif & positif & positif & positif & positif & negatif \\
\hline \multirow[t]{3}{*}{ Kesimpulan } & valid & valid & valid & valid & valid & valid & valid & $\begin{array}{l}\text { tdk. } \\
\text { valid }\end{array}$ \\
\hline & \multicolumn{8}{|c|}{ No. Item } \\
\hline & 9 & 10 & 11 & 12 & 13 & 14 & 15 & 16 \\
\hline $\mathbf{r}$ & \begin{tabular}{|c|}
0.4939 \\
\end{tabular} & 0.2449 & 0.5566 & 0.7579 & 0.3721 & 0.6306 & 0.5150 & 0.5642 \\
\hline Keputusan & positif & positif & positif & positif & positif & positif & positif & positif \\
\hline Kesimpulan & valid & valid & valid & valid & valid & valid & valid & valid \\
\hline
\end{tabular}


4) Uji Validitas untuk Variabel Promosi ( Promotion / $\mathrm{X}_{4}$ )

Berdasarkan hasil uji validitas terhadap 8 item pertanyaan ditunjukkan:

No. Item

\begin{tabular}{|c|c|c|c|c|c|c|c|c|}
\multicolumn{1}{c}{} & \multicolumn{1}{c}{1} & 2 & 3 & 4 & 5 & 6 & 7 & 8 \\
\hline r & $\mathbf{0 . 3 7 9 4}$ & $\mathbf{0 . 6 7 9 6}$ & $\mathbf{- 0 . 0 1 1 3}$ & $\mathbf{0 . 4 9 4 3}$ & $\mathbf{0 . 3 0 7 1}$ & $\mathbf{0 . 1 1 3 9}$ & $\mathbf{0 . 3 9 5 8}$ & $\mathbf{0 . 3 3 7 8}$ \\
\hline Keputusan & positif & positif & negatif & positif & positif & positif & positif & positif \\
\hline Kesimpulan & valid & valid & $\begin{array}{c}\text { tdk. } \\
\text { valid }\end{array}$ & valid & valid & valid & valid & valid \\
\hline
\end{tabular}

5) Uji Validitas untuk Variabel Orang ( People / $X_{5}$ )

Berdasarkan hasil uji validitas terhadap 6 item pertanyaan ditunjukkan

\begin{tabular}{|c|c|c|c|c|c|c|c|}
\hline & \multicolumn{6}{|c|}{ No. Item } & \multirow[b]{2}{*}{ 6) $\mathrm{U}$} \\
\hline & 1 & 2 & 3 & 4 & 5 & 6 & \\
\hline $\mathbf{R}$ & 0.7254 & 0.2466 & 0.5959 & 0.4763 & 0.3920 & 0.5143 & $\underset{j 1}{V^{1}}$ \\
\hline Keputusan & positif & positif & positif & positif & positif & positif & \\
\hline Kesimpulan & valid & valid & valid & valid & valid & valid & untuk \\
\hline
\end{tabular}

Berdasarkan hasil uji validitas terhadap 32 item pertanyaan ditunjukkan:

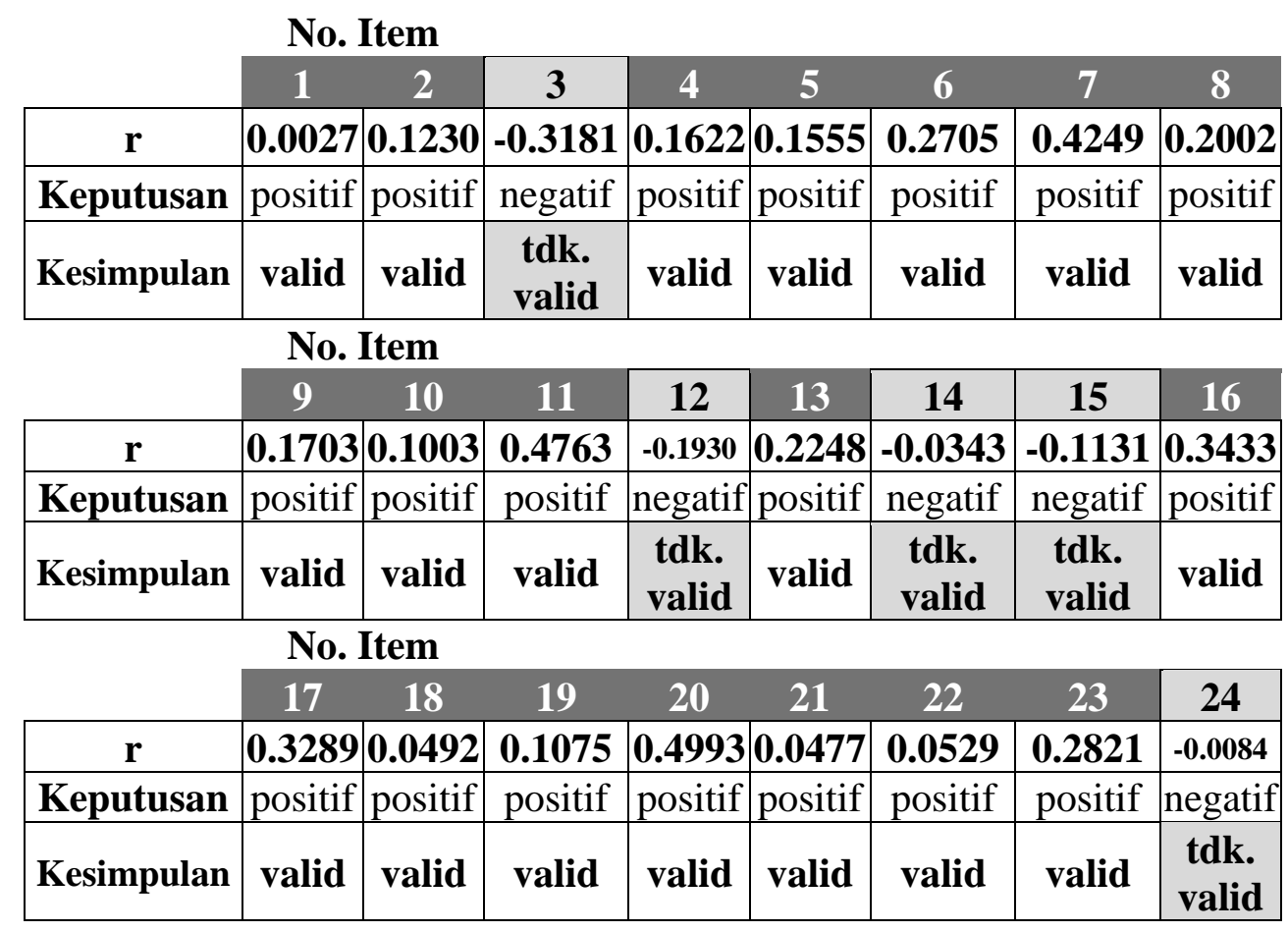




\begin{tabular}{|c|c|c|c|c|c|c|c|c|}
\cline { 2 - 7 } \multicolumn{1}{c|}{ No. Item } & 25 & 26 & 27 & 28 & 29 & 30 & 31 & 32 \\
\hline r & $\mathbf{0 . 1 2 1 4}$ & $\mathbf{0 . 0 7 1 4}$ & $\mathbf{0 . 4 1 5 5}$ & $\mathbf{0 . 0 9 4 3}$ & $\mathbf{0 . 3 0 0 1}$ & $\mathbf{0 . 2 3 1 3}$ & $\mathbf{0 . 3 7 1 7}$ & $\mathbf{0 . 0 4 2 0}$ \\
\hline Keputusan & positif & positif & positif & positif & positif & positif & positif & positif \\
\hline Kesimpulan & valid & valid & valid & valid & valid & valid & valid & valid \\
\hline
\end{tabular}

7) Uji Validitas untuk Variabel Bukti Fisik ( Physical Evidence / $\mathrm{X}_{7}$ ) Berdasarkan hasil uji validitas terhadap 14 item pertanyaan ditunjukkan:

\begin{tabular}{|c|c|c|c|c|c|c|c|}
\hline & \multicolumn{7}{|l|}{ No. Item } \\
\hline & 1 & 2 & 3 & 4 & 5 & 6 & 7 \\
\hline $\mathbf{r}$ & -0.1369 & 0.0217 & 0.3260 & -0.1051 & 0.3405 & 0.1529 & 0.1529 \\
\hline Keputusan & negatif & positif & positif & negatif & positif & positif & ositif \\
\hline \multirow[t]{3}{*}{ Kesimpulan } & $\begin{array}{l}\text { tdk. } \\
\text { valid }\end{array}$ & valid & valid & . & valid & valid & valid \\
\hline & \multicolumn{7}{|l|}{ No. Item } \\
\hline & 8 & 9 & 10 & 11 & 12 & 13 & 14 \\
\hline $\mathbf{r}$ & 0.0818 & 0.2085 & 0.1100 & 0.2591 & 0.2985 & 0.2878 & 0.1490 \\
\hline Keputusan & positif & positif & positif & positif & positif & positif & positif \\
\hline Kesimpulan & valid & valid & valid & valid & valid & valid & valid \\
\hline
\end{tabular}

8) Uji Validitas untuk Variabel keputusan konsumen menginap (Y).

Berdasarkan hasil uji validitas terhadap 11 item pertanyaan ditunjukkan:

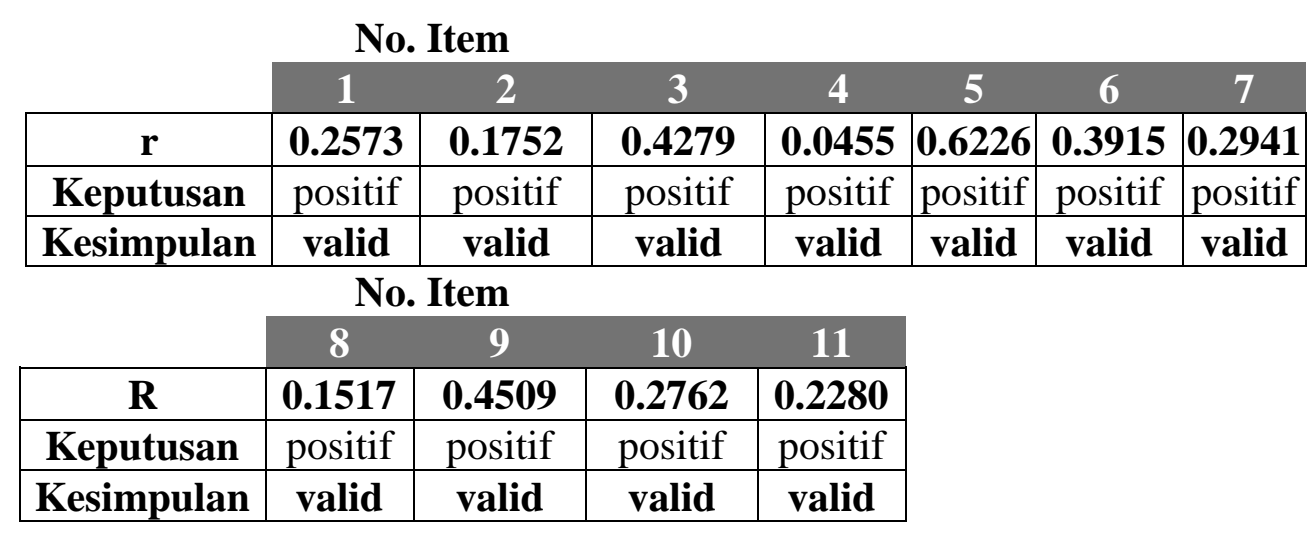

\section{b. Uji Reliabilitas}

1) Uji Reliabilitas untuk Variabel Produk ( Product $/ X_{1}$ )

Berdasarkan hasil uji reliabilitas ditunjukkan:

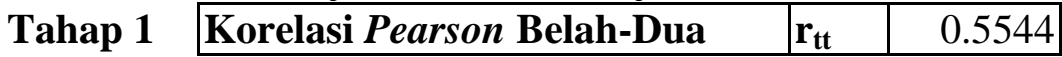


\begin{tabular}{c|r|r|} 
Tahap 2 Reliabilitas Spearman-Brown & $\mathbf{r}_{\text {tot }}$ & $\mathbf{0 . 7 1 3 4}$ \\
\cline { 2 - 3 } & Keputusan & positif \\
\cline { 3 - 3 } & Kesimpulan & reliabel \\
\cline { 3 - 4 }
\end{tabular}

2) Uji Reliabilitas untuk Variabel Harga ( Price / $X_{2}$ )

Berdasarkan hasil uji reliabilitas ditunjukkan:

\begin{tabular}{l|l|l|r|} 
Tahap 1 & Korelasi Pearson Belah-Dua & $\mathbf{r}_{\mathrm{tt}}$ & 0.5078 \\
\cline { 2 - 4 } Tahap 2 & Reliabilitas Spearman-Brown & $\mathbf{r}_{\text {tot }}$ & $\mathbf{0 . 6 7 3 6}$ \\
\cline { 2 - 4 } \multicolumn{2}{|r}{ Keputusan } & positif \\
\cline { 3 - 4 } & Kesimpulan & reliabel \\
\cline { 3 - 4 }
\end{tabular}

3) Uji Reliabilitas untuk Variabel Tempat ( Place / $\mathrm{X}_{3}$ )

Berdasarkan hasil uji reliabilitas ditunjukkan:

\begin{tabular}{|c|c|c|c|}
\hline Tahap 1 & Korelasi Pearson Belah-Dua & $\mathbf{r}_{\mathrm{tt}}$ & 0.8438 \\
\hline Tah & Reliabilitas Spearman-Brown & $\mathbf{r}_{\text {tot }}$ & 0.9153 \\
\hline & $\begin{array}{l}\text { Keput } \\
\text { Kesim }\end{array}$ & & $\begin{array}{r}\text { positif } \\
\text { reliabel }\end{array}$ \\
\hline
\end{tabular}

4) Uji Reliabilitas untuk Variabel Promosi ( Promotion / $\mathrm{X}_{4}$ )

Berdasarkan hasil uji reliabilitas ditunjukkan:

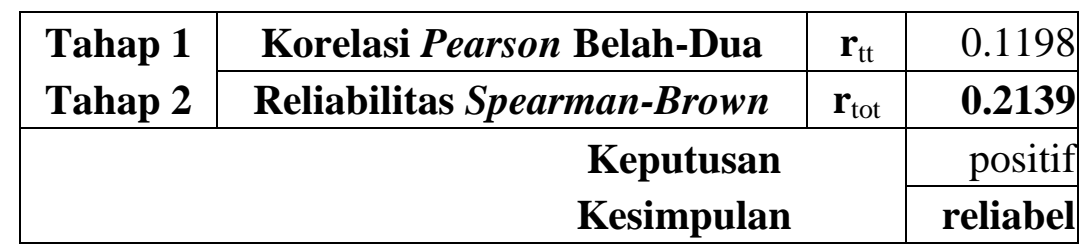

5) Uji Reliabilitas untuk Variabel Orang ( People / $\mathrm{X}_{5}$ )

Berdasarkan hasil uji reliabilitas ditunjukkan:

\begin{tabular}{|c|c|c|c|}
\hline \multirow{2}{*}{$\begin{array}{l}\text { Tahap } 1 \\
\text { Tahap } 2\end{array}$} & Korelasi Pearson Belah-Dua & $\mathbf{r}_{\mathrm{tt}}$ & 0.2807 \\
\hline & Reliabilitas Spearman-Brown & $\mathbf{r}_{\text {tot }}$ & 0.4383 \\
\hline \multirow{2}{*}{\multicolumn{3}{|c|}{$\begin{array}{l}\text { Keputusan } \\
\text { Kesimpulan }\end{array}$}} & positif \\
\hline & & & reliabel \\
\hline
\end{tabular}

6) Uji Reliabilitas untuk Variabel Proses ( Process / $\mathrm{X}_{6}$ )

Berdasarkan hasil uji reliabilitas ditunjukkan:

\begin{tabular}{|c|c|c|c|}
\hline Tahap 1 & Korelasi Pearson Belah-Dua & $\mathbf{r}_{\mathrm{tt}}$ & 0.2600 \\
\cline { 2 - 5 } Tahap 2 & Reliabilitas Spearman-Brown & $\mathbf{r}_{\mathrm{tot}}$ & $\mathbf{0 . 4 1 2 7}$ \\
\hline
\end{tabular}




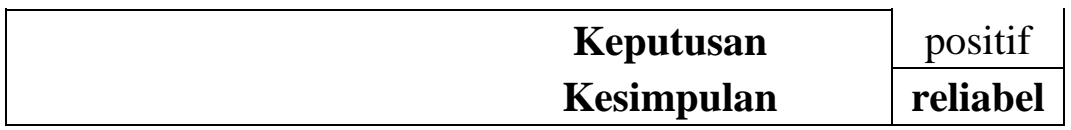

7) Variabel Variabel Bukti Fisik ( Physical Evidence / $\mathrm{X}_{7}$ )

Berdasarkan hasil uji reliabilitas ditunjukkan:

\begin{tabular}{|c|c|c|c|}
\hline Tahap 1 & Korelasi Pearson Belah-Dua & $\mathbf{r}_{\mathrm{tt}}$ & 0.1972 \\
\hline Tahap 2 & Reliabilitas Spearman-Brown & $\mathbf{r}_{\text {tot }}$ & 0.3294 \\
\hline & \multirow{2}{*}{\multicolumn{2}{|c|}{$\begin{array}{r}\text { Keputusan } \\
\text { Kesimpulan }\end{array}$}} & positif \\
\hline & & & reliabel \\
\hline
\end{tabular}

8) Uji Reliabilitas untuk Variabel keputusan menginap konsumen(Y).

Berdasarkan hasil uji reliabilitas ditunjukkan:

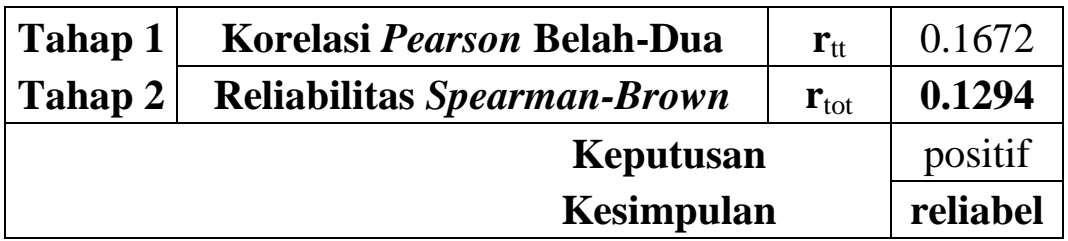

Hasil dari analisis data dengan menggunakan analisis jalur (path analysis) didasarkan pada Koefisien Korelasi Modifikasi Harun Al Rasjid untuk masingmasing variabel $\mathrm{X}$ dan $\mathrm{Y}$ dalam penelitian ini sebagai berikut:

a. Hasil perhitungan untuk Koefisien korelasi antara variabel $\mathrm{X}_{1}, \mathrm{X}_{2}$ dan $\mathrm{X}_{3}$ dengan variabel Y yang disusun dalam matriks korelasi sebagai berikut:

\begin{tabular}{|c|c|c|c|c|c|c|c|c|}
\hline Variabel & $\mathbf{X}_{\mathbf{1}}$ & $\mathbf{X}_{\mathbf{2}}$ & $\mathbf{X}_{\mathbf{3}}$ & $\mathbf{X}_{\mathbf{4}}$ & $\mathbf{X}_{\mathbf{5}}$ & $\mathbf{X}_{\mathbf{6}}$ & $\mathbf{X}_{\mathbf{3}}$ & $\mathbf{Y}$ \\
\hline $\mathrm{X}_{1}$ & 1.0000 & -0.2392 & 0.6029 & 0.6670 & 0.3797 & 0.7467 & 0,2567 & 0.6670 \\
\hline $\mathrm{X}_{2}$ & -0.2392 & 1.0000 & -0.1066 & 0.3797 & 0.7467 & 0,2567 & 0,3867 & 0.3797 \\
\hline $\mathrm{X}_{3}$ & 0.6029 & -0.1066 & 1.0000 & 0.7467 & 0,2567 & 0,3867 & 0,3454 & 0.7467 \\
\hline $\mathrm{X}_{4}$ & -0.1066 & 0.3797 & 0.7467 & 1.0000 & 0,3867 & 0,3454 & -0.1037 & 0.6670 \\
\hline $\mathrm{X}_{5}$ & 0.3797 & 0.7467 & 0,2567 & 0,3867 & 1.0000 & -0.1037 & 0.1792 & -0.1049 \\
\hline $\mathrm{X}_{6}$ & 0.7467 & 0,2567 & 0,3867 & 0,3454 & -0.1037 & 1.0000 & 0.0511 & 0.5360 \\
\hline $\mathrm{X}_{7}$ & 0,2567 & 0,3867 & 0,3454 & -0.1037 & 0.1792 & 0.0511 & 1.0000 & 0.1754 \\
\hline $\mathrm{Y}$ & 0.6670 & 0.3797 & 0.7467 & 0.6670 & -0.1049 & 0.5360 & 0.1754 & 1.0000 \\
\hline
\end{tabular}

b. Hasil perhitungan untuk Koefisien korelasi antar-variabel $\mathrm{X}$ (eksogenus atau independen) yang disusun dalam matriks invers korelasi sebagai berikut:

\begin{tabular}{|c|c|c|c|c|c|c|c|}
\hline Variabel & $\mathbf{X}_{\mathbf{1}}$ & $\mathbf{X}_{\mathbf{2}}$ & $\mathbf{X}_{\mathbf{3}}$ & $\mathbf{X}_{\mathbf{4}}$ & $\mathbf{X}_{\mathbf{5}}$ & $\mathbf{X}_{\mathbf{6}}$ & $\mathbf{X}_{\mathbf{3}}$ \\
\hline $\mathrm{X}_{1}$ & 1.6513 & 0.2921 & -0.9645 & 0.0627 & 0,1243 & 0,0785 & 0,1341 \\
\hline $\mathrm{X}_{2}$ & 0.2921 & 1.0632 & -0.0627 & 0,1243 & 0,0785 & 0,1341 & 0,2341 \\
\hline $\mathrm{X}_{3}$ & -0.9645 & -0.0627 & 1.5748 & 0,0785 & 0,1341 & 0,2341 & 0.1185 \\
\hline $\mathrm{X}_{4}$ & 0.0627 & 0,1243 & 0,0785 & 0,1341 & 1.0470 & 0.1185 & -0.1936 \\
\hline
\end{tabular}




\begin{tabular}{|c|c|c|c|c|c|c|c|}
\hline $\mathrm{X}_{5}$ & 0,1243 & 0,0785 & 0,1341 & 0,2341 & 0.1185 & 1.0160 & -0.0731 \\
\hline $\mathrm{X}_{6}$ & 0,0785 & 0,1341 & 0,2341 & 0.1185 & -0.1936 & -0.0731 & 1.0384 \\
\hline $\mathrm{X}_{7}$ & 0,1341 & 0,2341 & 0.1185 & -0.1936 & -0.0731 & 0,0134 & 0,1345 \\
\hline
\end{tabular}

c. Hasil perhitungan untuk Koefisien jalur $\operatorname{Pyx}_{\mathrm{i}}$; $(\mathrm{i}=1,2,3,4,5,6,7)$ sebagai berikut:

\begin{tabular}{|c|c|c|}
\hline Koefisien Jalur $\mathrm{X}_{1}$ terhadap Y & $\mathbf{p}_{\mathbf{Y} . \mathbf{X} 1}$ & 0.4922 \\
\hline Koefisien Jalur $\mathrm{X}_{2}$ terhadap Y & $\mathbf{p}_{I}$ & 0.5517 \\
\hline Koefisien Jalur $\mathrm{X}_{3}$ terhadap Y & $\mathbf{p}_{\mathbf{Y} . \mathbf{X} 3}$ & 0.5087 \\
\hline Koefisien Jalur $\mathrm{X}_{4}$ terhadap Y & $\mathbf{p}_{Y . X 4}$ & 0.1865 \\
\hline Koefisien Jalur $\mathrm{X}_{5}$ terhadap Y & $\mathbf{p}_{\mathbf{Y} . \mathbf{X 5}}$ & 0.0704 \\
\hline Koefisien Jalur $\mathrm{X}_{6}$ terhadap Y & $\mathbf{p}_{\mathbf{Y} . \mathbf{} 6}$ & 0.5193 \\
\hline Koefisien Jalur $\mathrm{X}_{7}$ terhadap Y & $\mathbf{p}_{\mathbf{Y} . \mathbf{X} 7}$ & 0.1632 \\
\hline
\end{tabular}

d. Hasil perhitungan untuk Koefisien determinasi multipel $\left(\mathrm{R}^{2} \mathrm{Y}\right.$.X1X2 X3 X4 X5 X6 X7);

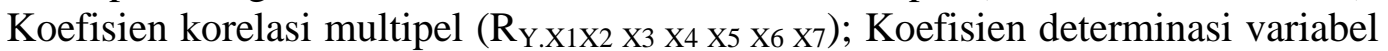
lain terhadap $\mathrm{Y}\left(\mathrm{P}_{\mathrm{Y} . \varepsilon}^{2}\right)$ dan Koefisien jalur variabel lain terhadap $\mathrm{Y}\left(\mathrm{P}_{\mathrm{Y} . \varepsilon}\right)$ sebagai berikut:

\begin{tabular}{|l|r|r|}
\hline Koefisien Determinasi Multipel & $\mathbf{R}^{2}$ Y.X1X2X3 X4 X5 X6 & $\mathbf{0 . 9 1 7 6}$ \\
X7 & \\
\hline Koefisien Korelasi Multipel & $\mathbf{R}_{\text {Y.X1X2X3 X4 X5 X6 }}$ & $\mathbf{0 . 9 5 7 9}$ \\
& $\mathbf{p}^{2}$ Y. & $\mathbf{0 . 0 8 2 4}$ \\
\hline $\begin{array}{l}\text { Koefisien Determinasi variabel lain } \\
\text { terhadap Y }\end{array}$ & $\mathbf{p}_{\mathbf{Y} . \varepsilon}$ & $\mathbf{0 . 2 8 7 0}$ \\
\hline Koefisien Jalur variabel lain terhadap Y & & \\
\hline
\end{tabular}

e. Berdasarkan pada hasil perhitungan yang ditunjukkan pada Tabel-tabel di atas, maka berbagai koefisien jalur dari variabel $X_{1}, X_{2} X_{3} X_{4} X_{5} X_{6}$ dan $X_{7}$ serta variabel lain terhadap variabel $\mathrm{Y}$ dalam penelitian ini dapat digambarkan 


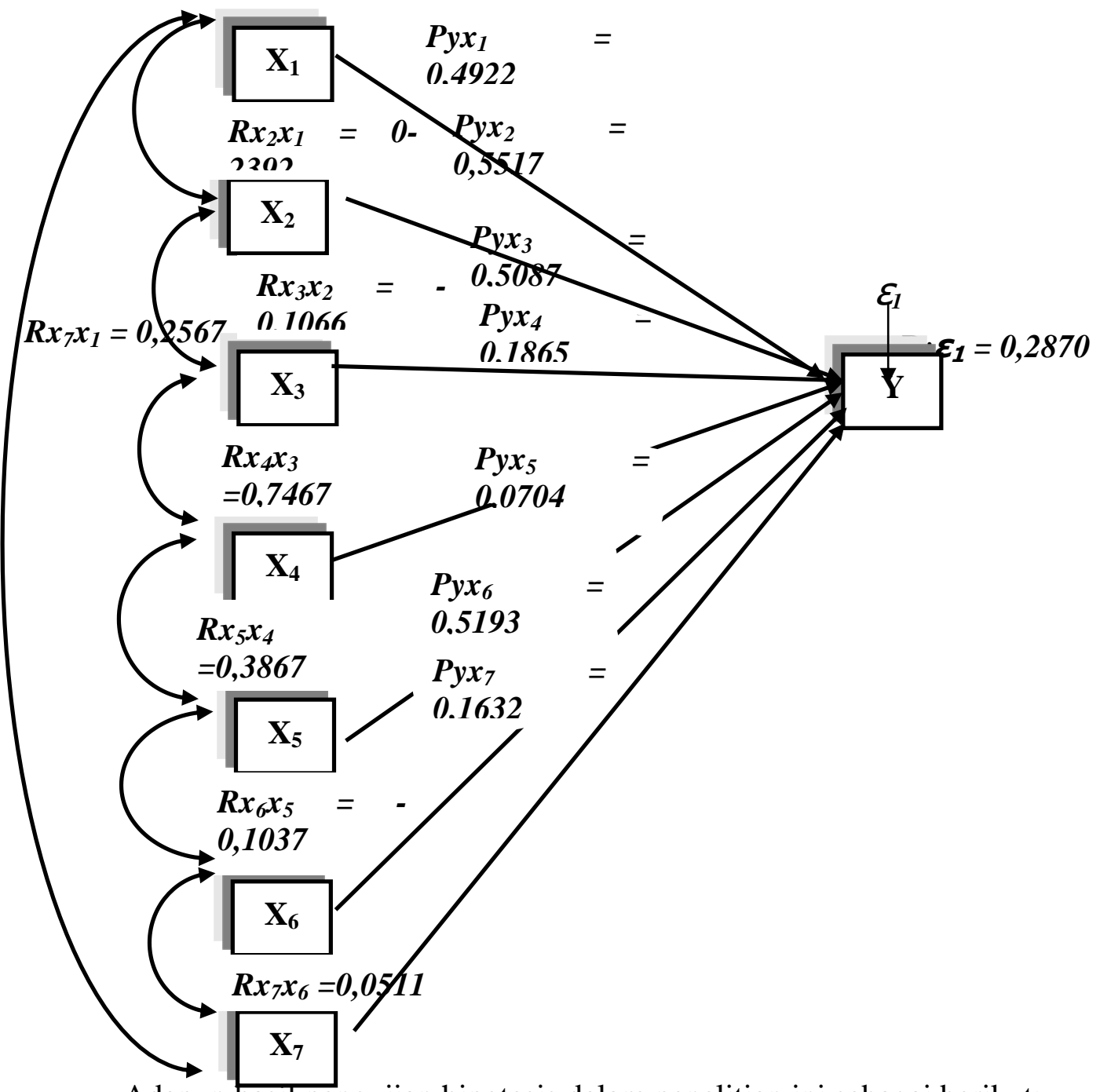

Adapun hasil pengujian hipotesis dalam penelitian ini sebagai berikut:

a. Pengujian secara bersama-sama

Hasil dari pengujian secara bersama-sama terhadap hipotesis statistik yang pertama dalam penelitian ini sebagai berikut:

\section{Uji Keseluruhan}

\begin{tabular}{|l|l|l|l|l|}
\hline F & $\mathbf{4 4 . 5 4 5 2}$ \\
\hline
\end{tabular}

$>$

$\mathbf{F}_{\mathbf{0 . 0 5} ; 3 ; 12}$

\begin{tabular}{|r|}
\hline p-value \\
\hline 0.0000 \\
\hline
\end{tabular}

Keputusan: signifikan pada taraf kesalahan $\mathbf{5 \%}$

Kesimpulan: Minimal terdapat satu koefisien jalur yang berarti 
Berdasarkan pada hasil Uji Keseluruhan di atas, ditunjukkan bahwa nilai $\mathrm{F}_{\text {hitung }}=$ $44.5452>\mathrm{F}_{\text {tabel }}=3.4093$ pada tingkat signifikan 95\% $(\alpha=5 \%)$ dan degree of freedom 3/12 ( $\mathrm{df}=3: 16-3-1)$, sehingga sesuai dengan ketentuan dalam kriteria pengujian jika $\mathrm{F}_{\text {hitung }}>\mathrm{F}_{\text {tabel }}$ maka $\mathrm{H}_{1}$ diterima atau $\mathrm{H}_{0}$ ditolak.

Adapun nilai koefisien determinasi total $\left(\mathrm{R}^{2}{ }_{\left.\mathrm{Y} . \mathrm{X}_{1 \times 2} \mathrm{X}_{3} \mathrm{X}_{4} \mathrm{X}_{5} \mathrm{X}_{6} \mathrm{X}_{7}\right)}\right)$ atau keeratan hubungannya sebesar 91,76\%, artinya keputusan menginap konsumen (Y) sebesar $91,76 \%$ dipengaruhi secara simultan oleh product $\left(\mathrm{X}_{1}\right)$, price $\left(\mathrm{X}_{2}\right)$ place $\left(\mathrm{X}_{3}\right)$, promotion $\left(\mathrm{X}_{4}\right)$, people $\left(\mathrm{X}_{5}\right)$, process $\left(\mathrm{X}_{6}\right)$, physical evidence $\left(\mathrm{X}_{7}\right)$. Mengacu pada

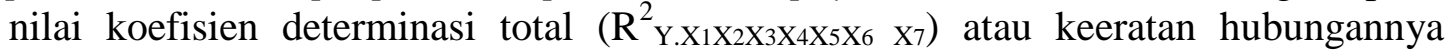
sebesar $91,76 \%$ tersebut, maka dapat disimpulkan bahwa variabel $X_{1}, X_{2}, X_{3}, X_{4}, X_{5}$, $\mathrm{X}_{6}, \mathrm{X}_{7}$ mempunyai tingkat pengaruh yang "very high correlation" terhadap variabel $\mathrm{Y}$ (berdasarkan tafsiran dari Guilford, 1956:145).

\section{b. Pengujian secara parsial}

1) Variabel $X_{1}$ terhadap variabel $Y$

Hasil dari pengujian secara parsial variabel $\mathrm{X}_{1}$ terhadap variabel $\mathrm{Y}$ sbb:

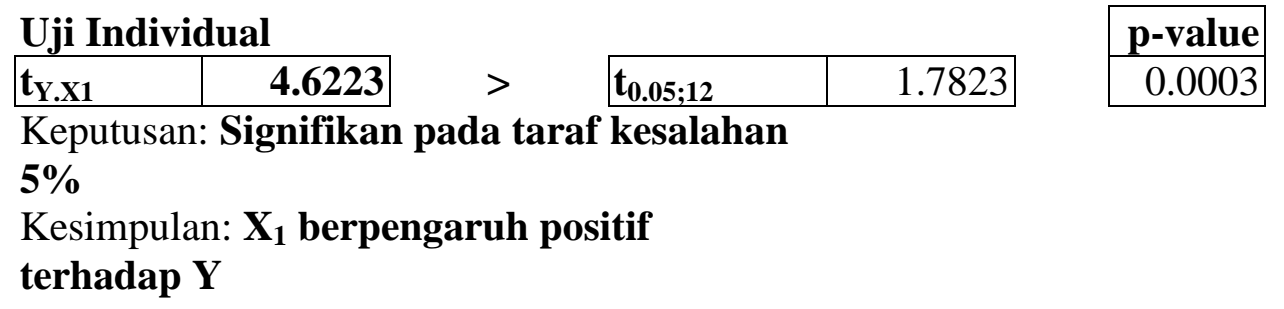

Berdasarkan pada hasil Uji Individual di atas, ditunjukkan bahwa nilai $t_{\text {hitung }}=$ $4.6223>\mathrm{t}_{\text {tabel }}=1.7823$ pada tingkat signifikan $95 \%(\alpha=5 \%)$ dan degree of freedom $12(\mathrm{df}=16-3-1)$, sehingga sesuai dengan ketentuan dalam kriteria pengujian jika $t_{\text {hitung }}>t_{\text {tabel }}$ maka $\mathrm{H}_{1}$ diterima atau $\mathrm{H}_{0}$ ditolak. Adapun hasil pengujian untuk mengetahui besarnya pengaruh secara langsung dan tidak langsung variabel $\mathrm{X}_{1}$ terhadap variabel $Y$ dalam penelitian ini sebagai berikut:

\begin{tabular}{|l|l|l|l|l|l|l|l|l|l|c|}
\hline & Pengaruh \\
& Langsung & \multicolumn{7}{|c|}{ Pengaruh Tak Langsung Melalui } & Sub & Total \\
\cline { 3 - 8 } & $\mathbf{X}_{\mathbf{1}}$ & $\mathbf{X}_{\mathbf{2}}$ & $\mathbf{X}_{\mathbf{3}}$ & $\mathbf{X}_{\mathbf{4}}$ & $\mathbf{X}_{\mathbf{5}}$ & $\mathbf{X}_{\mathbf{6}}$ & $\mathbf{X}_{\mathbf{7}}$ & Total & \\
\hline $\mathbf{X}_{\mathbf{1}}$ & $18,67 \%$ & & $-6,49 \%$ & $5,15 \%$ & $-2,99 \%$ & $-3,90 \%$ & $4,31 \%$ & $0,43 \%$ & $-3,49 \%$ & $15,18 \%$ \\
\hline
\end{tabular}

Mengacu pada hasil pengujian di atas, ditunjukkan bahwa:

Pengaruh langsung variabel $\mathrm{X}_{1}$ terhadap variabel $\mathrm{Y}$ sebesar $18.67 \%$ (positif). Pengaruh tidak langsung variabel $\mathrm{X}_{1}$ melalui variabel $\mathrm{X}_{2}$ terhadap variabel $\mathrm{Y}$ sebesar $-6.49 \%$ (negatif), melalui variabel $\mathrm{X}_{3}$ sebesar $5,15 \%$ (positif), melalui variabel $\mathrm{X}_{4}$ sebesar $-2,99 \%$ (negatif), melalui variabel $\mathrm{X}_{5}$ sebesar $-3,90 \%$ (negatif), melalui variabel $\mathrm{X}_{6}$ sebesar $4,31 \%$ (positif), dan melalui variabel $\mathrm{X}_{7}$ sebesar $0,43 \%$ (positif). 
Berdasarkan pada hasil pengujian tersebut, maka pengaruh total variabel $\mathrm{X}_{1}$ terhadap variabel Y sebesar $15.18 \%$ (positif).

2) Variabel $X_{2}$ terhadap variabel $Y$

Hasil dari pengujian secara parsial variabel $\mathrm{X}_{2}$ terhadap variabel $\mathrm{Y}$ sbb:

\section{Uji Individual}

\begin{tabular}{|c|c|c|c|c|c|}
\hline Jj & & & & & p-value \\
\hline$t_{Y . X 2}$ & 6.4567 & $>$ & $t_{0.05 ; 12}$ & 1.7823 & \\
\hline
\end{tabular}

Keputusan: Signifikan pada taraf kesalahan $\mathbf{5 \%}$

Kesimpulan: $\mathbf{X}_{\mathbf{2}}$ berpengaruh positif terhadap $\mathbf{Y}$

Berdasarkan pada hasil Uji Individual di atas, ditunjukkan bahwa nilai $t_{\text {hitung }}=$ $6.4567>\mathrm{t}_{\text {tabel }}=1.7823$ pada tingkat signifikan $95 \%(\alpha=5 \%)$ dan degree of freedom 12 (df = 16-3-1), sehingga sesuai dengan ketentuan dalam kriteria pengujian jika $t_{\text {hitung }}>t_{\text {tabel }}$ maka $\mathrm{H}_{1}$ diterima atau $\mathrm{H}_{0}$ ditolak. Adapun hasil pengujian untuk mengetahui besarnya pengaruh secara langsung dan tidak langsung variabel $\mathrm{X}_{2}$ terhadap variabel Y dalam penelitian ini sebagai berikut:

\begin{tabular}{|l|l|l|l|l|l|l|l|l|l|l|}
\hline & Pengaruh & \multicolumn{7}{|c|}{ Pengaruh Tak Langsung Melalui } & SubTotal & Total \\
\cline { 3 - 9 } & Langsung & $\mathbf{X}_{\mathbf{1}}$ & $\mathbf{X}_{\mathbf{2}}$ & $\mathbf{X}_{\mathbf{3}}$ & $\mathbf{X}_{\mathbf{4}}$ & $\mathbf{X}_{\mathbf{5}}$ & $\mathbf{X}_{\mathbf{6}}$ & $\mathbf{X}_{\mathbf{7}}$ & & \\
\hline $\mathbf{X}_{\mathbf{2}}$ & $20,15 \%$ & $-6,49 \%$ & & $-2,99 \%$ & $-3,90 \%$ & $4,31 \%$ & $0,43 \%$ & $-0,23 \%$ & $-8,87 \%$ & $11,28 \%$ \\
\hline
\end{tabular}

Mengacu pada hasil pengujian di atas, ditunjukkan bahwa:

Pengaruh langsung variabel $\mathrm{X}_{2}$ terhadap variabel $\mathrm{Y}$ sebesar $20.15 \%$ (positif), Pengaruh tidak langsung variabel $\mathrm{X}_{2}$ melalui variabel $\mathrm{X}_{1}$ terhadap variabel $\mathrm{Y}$ sebesar $-6.49 \%$ (negatif), melalui variabel $\mathrm{X}_{3}$ sebesar $-2,99 \%$ (negatif), melalui variabel $\mathrm{X}_{4}$ sebesar $-3,90 \%$ (negatif), melalui variabel $\mathrm{X}_{5}$ sebesar $4,31 \%$ (positif), melalui variabel $\mathrm{X}_{6}$ sebesar $0,43 \%$ (positif), dan melalui variabel $\mathrm{X}_{7}$ sebesar $-0,23 \%$ (negatif). Berdasarkan pada hasil pengujian tersebut, maka pengaruh total variabel $\mathrm{X}_{2}$ terhadap variabel Y sebesar $11.28 \%$ (positif).

3) Variabel $X_{3}$ terhadap variabel $Y$

Hasil dari pengujian secara parsial variabel $\mathrm{X}_{3}$ terhadap variabel $\mathrm{Y}$ sbb:

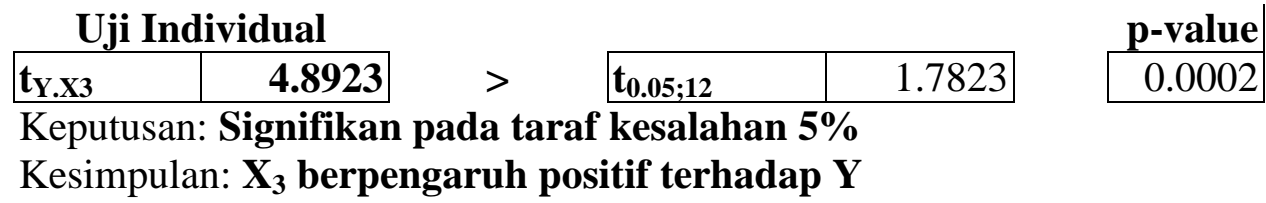

Berdasarkan pada hasil Uji Individual di atas, ditunjukkan bahwa nilai $\mathrm{t}_{\text {hitung }}=$ $4.8923>\mathrm{t}_{\text {tabel }}=1.7823$ pada tingkat signifikan $95 \%(\alpha=5 \%)$ dan degree of freedom 12 (df = 16-3-1), sehingga sesuai dengan ketentuan dalam kriteria pengujian jika $t_{\text {hitung }}>t_{\text {tabel }}$ maka $\mathrm{H}_{1}$ diterima atau $\mathrm{H}_{0}$ ditolak. Adapun hasil pengujian untuk mengetahui besarnya pengaruh secara langsung dan tidak langsung variabel $\mathrm{X}_{3}$ terhadap variabel Y dalam penelitian ini sebagai berikut: 


\begin{tabular}{|c|c|c|c|c|c|c|c|c|c|c|}
\hline & \multirow{2}{*}{$\begin{array}{l}\text { Pengaruh } \\
\text { Langsung }\end{array}$} & \multicolumn{7}{|c|}{ Pengaruh Tak Langsung Melalui } & \multirow{2}{*}{$\begin{array}{l}\text { Sub } \\
\text { Total }\end{array}$} & \multirow[t]{2}{*}{ Total } \\
\hline & & $X_{1}$ & $X_{2}$ & $X_{3}$ & $X_{4}$ & $X_{5}$ & $X_{6}$ & $X_{7}$ & & \\
\hline $\mathbf{X}_{3}$ & $10,10 \%$ & $5,15 \%$ & $-2,99 \%$ & & $4,31 \%$ & $0,43 \%$ & $-0,23 \%$ & $0,14 \%$ & $6,81 \%$ & $\begin{array}{l}16,91 \\
\%\end{array}$ \\
\hline
\end{tabular}

Mengacu pada hasil pengujian di atas, ditunjukkan bahwa:

Pengaruh langsung variabel $\mathrm{X}_{3}$ terhadap variabel $\mathrm{Y}$ sebesar $10,10 \%$ (positif), Pengaruh tidak langsung variabel $\mathrm{X}_{3}$ melalui variabel $\mathrm{X}_{1}$ terhadap variabel $\mathrm{Y}$ sebesar $5,15 \%$ (positif), melalui variabel $X_{2}$ sebesar $-2,99 \%$ (negatif), melalui variabel $X_{4}$ sebesar $4,31 \%$ (positif), melalui variabel $\mathrm{X}_{5}$ sebesar $0,43 \%$ (positif), melalui variabel $\mathrm{X}_{6}$ sebesar $-0,23 \%$ (negatif), dan melalui variabel $\mathrm{X}_{7}$ sebesar $0,14 \%$ (positif). Berdasarkan pada hasil pengujian tersebut, maka pengaruh total variabel $\mathrm{X}_{3}$ terhadap variabel Y sebesar $16.91 \%$ (positif).

4) Variabel $X_{4}$ terhadap variabel $Y$

Hasil dari pengujian secara parsial variabel $\mathrm{X}_{4}$ terhadap variabel $\mathrm{Y}$ sbb:

\section{Uji Individual}

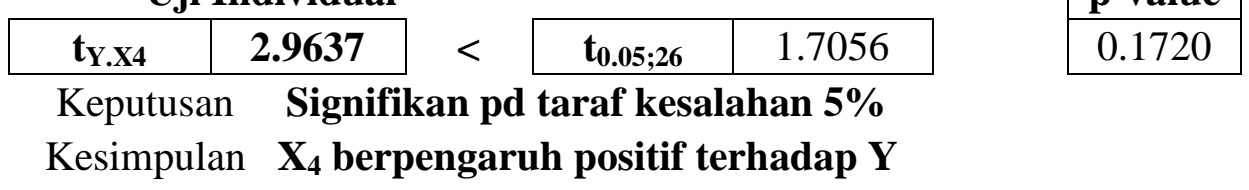

Berdasarkan pada hasil Uji Individual di atas, ditunjukkan bahwa nilai $\mathrm{t}_{\text {hitung }}=$ $2,9637>\mathrm{t}_{\text {tabel }}=1,7056$ pada tingkat signifikan $95 \%(\alpha=5 \%)$ dan degree of freedom 26 (df = 29-2-1), sehingga sesuai dengan ketentuan dalam kriteria pengujian jika $t_{\text {hitung }}>t_{\text {tabel }}$ maka $\mathrm{H}_{1}$ diterima atau $\mathrm{H}_{0}$ ditolak.

Adapun hasil pengujian untuk mengetahui besarnya pengaruh secara langsung dan tidak langsung variabel $\mathrm{X}_{4}$ terhadap variabel $\mathrm{Y}$ sebagai berikut:

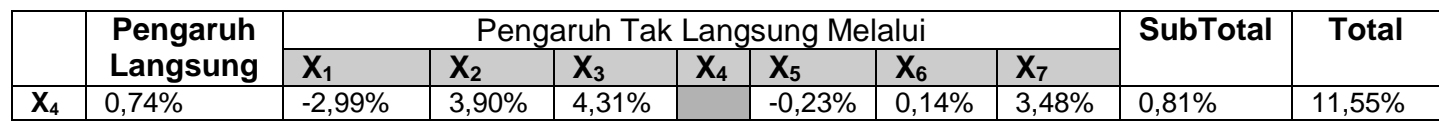

Mengacu pada hasil pengujian di atas, ditunjukkan bahwa:

Pengaruh langsung variabel $\mathrm{X}_{4}$ terhadap variabel $\mathrm{Y}$ sebesar $0,74 \%$ (positif), Pengaruh tidak langsung variabel $\mathrm{X}_{4}$ melalui variabel $\mathrm{X}_{1}$ terhadap variabel $\mathrm{Y}$ sebesar $-2,99 \%$ (negatif), melalui variabel $X_{2}$ sebesar $-3,90 \%$ (negatif), melalui variabel $X_{3}$ sebesar $4,31 \%$ (positif), melalui variabel $\mathrm{X}_{5}$ sebesar $-0,23 \%$ (negatif), melalui variabel $\mathrm{X}_{6}$ sebesar $0,14 \%$ (positif), dan melalui variabel $\mathrm{X}_{7}$ sebesar 3,48\% (positif). Berdasarkan pada hasil tersebut, maka pengaruh total variabel $\mathrm{X}_{4}$ terhadap variabel $\mathrm{Y}$ sebesar $11,55 \%$ (positif).

5) Variabel $X_{5}$ terhadap variabel $Y$

Hasil dari pengujian secara parsial variabel $\mathrm{X}_{5}$ terhadap variabel $\mathrm{Y}$ sbb: 
Uji Individual

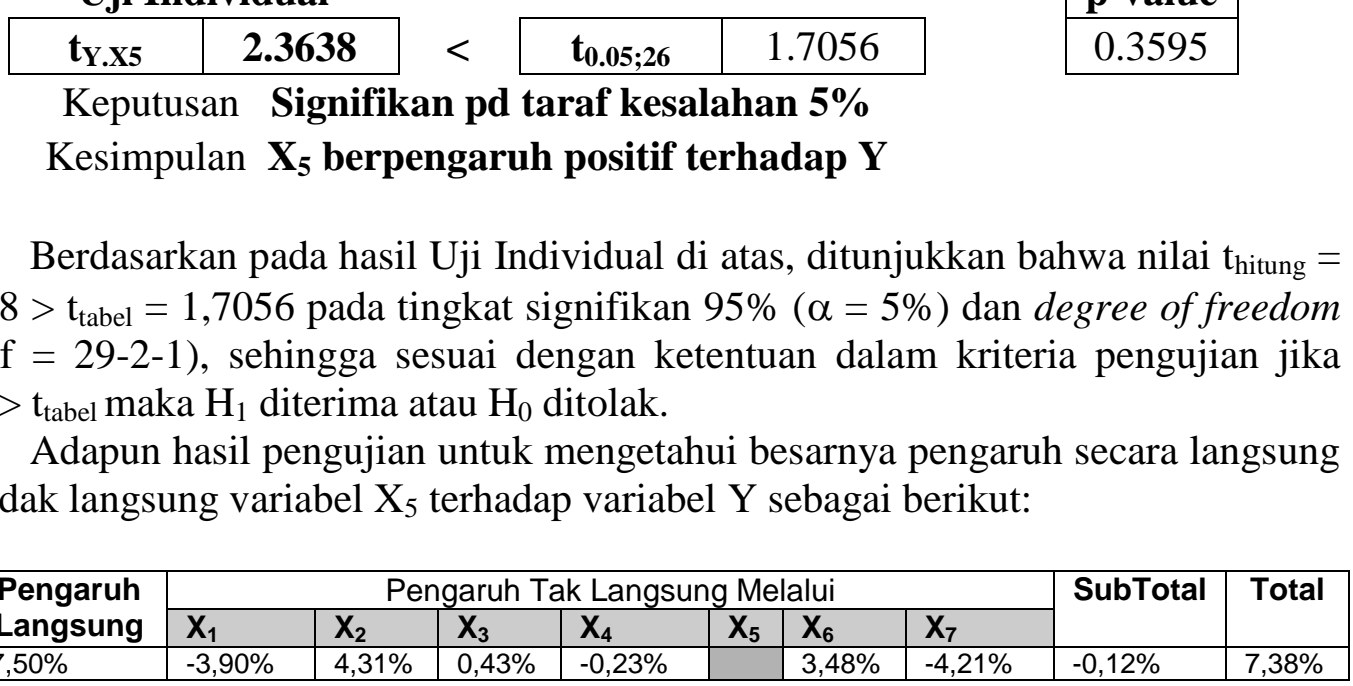

Mengacu pada hasil pengujian di atas, ditunjukkan bahwa:

Pengaruh langsung variabel $\mathrm{X}_{5}$ terhadap variabel $\mathrm{Y}$ sebesar 7,50\% (positif), Pengaruh tidak langsung variabel $\mathrm{X}_{5}$ melalui variabel $\mathrm{X}_{1}$ terhadap variabel $\mathrm{Y}$ sebesar $-3,90 \%$ (negatif), melalui variabel $\mathrm{X}_{2}$ sebesar $4,31 \%$ (positif), melalui variabel $\mathrm{X}_{3}$ sebesar $0,43 \%$ (positif), melalui variabel $\mathrm{X}_{4}$ sebesar $-0,23 \%$ (negatif), melalui variabel $\mathrm{X}_{6}$ sebesar 3,48\% (positif), melalui variabel $\mathrm{X}_{7}$ sebesar $-4,21 \%$ (positif). Berdasarkan pada hasil pengujian tersebut, maka pengaruh total variabel $\mathrm{X}_{5}$ terhadap variabel Y sebesar 7,38\% (positif).

6) Variabel $X_{6}$ terhadap variabel $Y$

Hasil dari pengujian secara parsial variabel $\mathrm{X}_{6}$ terhadap variabel $\mathrm{Y}$ sbb:

\section{Uji Individual}

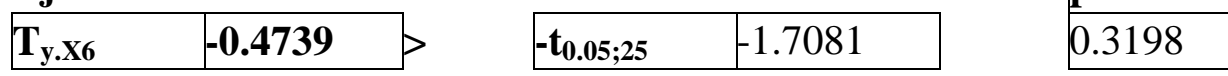

Keputusan Signifikan pd taraf kesalahan 5\%

Kesimpulan : $\mathbf{X}_{\mathbf{6}}$ berpengaruh positif terhadap $\mathbf{Y}$

Berdasarkan pada hasil Uji Individual di atas, ditunjukkan bahwa nilai thitung $=$ $-0,4739>\mathrm{t}_{\text {tabel }}=-1,7081$ pada tingkat signifikan 95\% $(\alpha=5 \%)$ dan degree of freedom $25(\mathrm{df}=29-3-1)$, sehingga sesuai dengan ketentuan dalam kriteria pengujian jika $\mathrm{t}_{\text {hitung }}>\mathrm{t}_{\text {tabel }}$ maka $\mathrm{H}_{1}$ diterima atau $\mathrm{H}_{0}$ ditolak.

Adapun hasil pengujian untuk mengetahui besarnya pengaruh secara langsung dan tidak langsung variabel $\mathrm{X}_{6}$ terhadap variabel $\mathrm{Y}$ sebagai berikut:

\begin{tabular}{|l|l|l|l|l|l|l|l|l|l|l|}
\hline & Pengaruh \\
& Langsung & \multicolumn{7}{|c|}{ Pengaruh Tak Langsung Melalui } & SubTotal & Total \\
\cline { 3 - 10 } & $\mathbf{X}_{\mathbf{1}}$ & $\mathbf{X}_{\mathbf{2}}$ & $\mathbf{X}_{3}$ & $\mathbf{X}_{\mathbf{4}}$ & $\mathbf{X}_{5}$ & $\mathbf{X}_{\mathbf{6}}$ & $\mathbf{X}_{\mathbf{7}}$ & & \\
\hline $\mathbf{X}_{6}$ & $5,75 \%$ & $4,31 \%$ & $0,43 \%$ & $-0,23 \%$ & $0,14 \%$ & $3,48 \%$ & & $5,17 \%$ & $13,30 \%$ & $19,05 \%$ \\
\hline
\end{tabular}


Mengacu pada hasil pengujian di atas, ditunjukkan bahwa:

Pengaruh langsung variabel $\mathrm{X}_{6}$ terhadap variabel $\mathrm{Y}$ sebesar 5,75\% (positif), Pengaruh tidak langsung variabel $\mathrm{X}_{6}$ melalui variabel $\mathrm{X}_{1}$ terhadap variabel $\mathrm{Y}$ sebesar $4,31 \%$ (positif), melalui variabel $\mathrm{X}_{2}$ sebesar $0,43 \%$ (positif), melalui variabel $\mathrm{X}_{3}$ sebesar $-0,23 \%$ (negatif), melalui variabel $X_{4}$ sebesar $0,14 \%$ (positif), melalui variabel $\mathrm{X}_{5}$ sebesar $3,48 \%$ (positif), dan melalui variabel $\mathrm{X}_{7}$ sebesar $5,17 \%$ (positif). Berdasarkan pada hasil tersebut, maka pengaruh total variabel $\mathrm{X}_{6}$ terhadap variabel $\mathrm{Y}$ sebesar 19,05\% (positif).

7). Hasil dari pengujian secara parsial variabel $X_{7}$ terhadap variabel $Y$ sbb :

\section{Uji Individual}

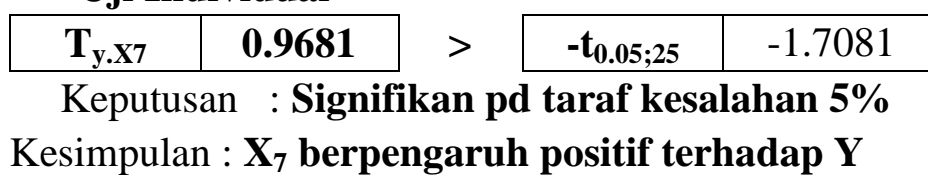

Berdasarkan pada hasil Uji Individual di atas, ditunjukkan bahwa nilai $\mathrm{t}_{\text {hitung }}=$ $0,9681>\mathrm{t}_{\text {tabel }}=-1,7081$ pada tingkat signifikan $95 \%(\alpha=5 \%)$ dan degree of freedom 25 (df = 29-3-1), sehingga sesuai dengan ketentuan dalam kriteria pengujian jika $\mathrm{t}_{\text {hitung }}>\mathrm{t}_{\text {tabel }}$ maka $\mathrm{H}_{1}$ diterima atau $\mathrm{H}_{0}$ ditolak.

Adapun hasil pengujian untuk mengetahui besarnya pengaruh secara langsung dan tidak langsung variabel $\mathrm{X}_{6}$ terhadap variabel $\mathrm{Y}$ sebagai berikut:

\begin{tabular}{|c|c|c|c|c|c|c|c|c|c|c|}
\hline & \multirow{2}{*}{$\begin{array}{l}\text { Pengaruh } \\
\text { Langsung }\end{array}$} & \multicolumn{7}{|c|}{ Pengaruh Tak Langsung Melalui } & \multirow[t]{2}{*}{ SubTotal } & \multirow[t]{2}{*}{ Total } \\
\hline & & $\overline{X_{1}}$ & $\mathbf{X}_{2}$ & $X_{3}$ & $\mathrm{X}_{4}$ & $X_{5}$ & $\mathbf{X}_{6}$ & $\overline{X_{7}}$ & & \\
\hline $\mathbf{X}_{7}$ & $7,57 \%$ & $0,43 \%$ & $-0,23 \%$ & $0,14 \%$ & $3,48 \%$ & $-4,21 \%$ & 5,17 & & $4,78 \%$ & $12,35 \%$ \\
\hline
\end{tabular}

Mengacu pada hasil pengujian di atas, ditunjukkan bahwa:

Pengaruh langsung variabel $\mathrm{X}_{7}$ terhadap variabel $\mathrm{Y}$ sebesar 7,57\% (positif), Pengaruh tidak langsung $\mathrm{X}_{7}$ melalui variabel $\mathrm{X}_{1}$ terhadap variabel $\mathrm{Y}$ sebesar $0,43 \%$ (positif), melalui variabel $\mathrm{X}_{2}$ sebesar $-0,23 \%$ (negatif), melalui variabel $\mathrm{X}_{3}$ sebesar $0,14 \%$ (positif), melalui variabel $\mathrm{X}_{4}$ sebesar $3,48 \%$ (positif), melalui variabel $\mathrm{X}_{5}$ sebesar $-4,21 \%$ (negatif), dan melalui variabel $\mathrm{X}_{6}$ sebesar $5,17 \%$ (positif). Berdasarkan pada hasil pengujian tersebut, maka pengaruh total variabel $\mathrm{X}_{6}$ terhadap variabel Y sebesar 12,35\% (positif).

Adapun hasil pengujian hipotesis dalam penelitian ini secara keseluruhan sesuai dengan pengujian secara simultan dan parsial sebagai berikut: 


\begin{tabular}{|c|c|c|c|c|c|c|c|c|c|c|}
\hline & \multirow{2}{*}{$\begin{array}{l}\text { Pengaruh } \\
\text { Langsung }\end{array}$} & \multicolumn{7}{|c|}{ Pengaruh Tak Langsung Melalui } & \multirow{2}{*}{$\begin{array}{c}\text { SubTo } \\
\text { tal }\end{array}$} & \multirow[t]{2}{*}{ Total } \\
\hline & & $X_{1}$ & $X_{2}$ & $X_{3}$ & $X_{4}$ & $X_{5}$ & $X_{6}$ & $X_{7}$ & & \\
\hline $\mathrm{X}_{1}$ & $18,67 \%$ & & $-6,49 \%$ & $5,15 \%$ & $-2,99 \%$ & $-3,90 \%$ & $4,31 \%$ & $0,43 \%$ & $-3,49 \%$ & $15,18 \%$ \\
\hline$X_{2}$ & $20,15 \%$ & $-6,49 \%$ & & $-2,99 \%$ & $-3,90 \%$ & $4,31 \%$ & $0,43 \%$ & $-0,23 \%$ & $-8,87 \%$ & $11,28 \%$ \\
\hline$X_{3}$ & $10,10 \%$ & $5,15 \%$ & $-2,99 \%$ & & $4,31 \%$ & $0,43 \%$ & $-0,23 \%$ & $0,14 \%$ & $6,81 \%$ & $16,91 \%$ \\
\hline $\mathbf{X}_{4}$ & $10,74 \%$ & $-2,99 \%$ & $-3,90 \%$ & $4,31 \%$ & & $-0,23 \%$ & $0,14 \%$ & $3,48 \%$ & $0,81 \%$ & $11,55 \%$ \\
\hline$X_{5}$ & $7,5 \%$ & $-3,90 \%$ & $4,31 \%$ & $0,43 \%$ & $-0,23 \%$ & & $3,48 \%$ & $-4,21 \%$ & $-0,12 \%$ & $7,38 \%$ \\
\hline$X_{6}$ & $5,75 \%$ & $4,31 \%$ & $0,43 \%$ & $-0,23 \%$ & $0,14 \%$ & $3,48 \%$ & & $5,17 \%$ & $13,30 \%$ & $19,05 \%$ \\
\hline$X_{7}$ & $7,57 \%$ & $0,43 \%$ & $-0,23 \%$ & $0,14 \%$ & $3,48 \%$ & $-4,21 \%$ & $5,17 \%$ & & $4,78 \%$ & $12,35 \%$ \\
\hline \multicolumn{10}{|c|}{ Pengaruh total variabel $\mathrm{X}_{1}, \mathrm{X}_{2}, \mathrm{X}_{3}, \mathrm{X}_{4}, \mathrm{X}_{5}, \mathrm{X}_{6}$, dan $\mathrm{X}_{7}$ terhadap Y } & $93,70 \%$ \\
\hline \multicolumn{10}{|c|}{ Pengaruh variabel $\mathrm{X}_{1}, \mathrm{X}_{2}, \mathrm{X}_{3}, \mathrm{X}_{4}, \mathrm{X}_{5}, \mathrm{X}_{6}$, dan $\mathrm{X}_{7}$ terhadap $\mathrm{Y}$} & $6,30 \%$ \\
\hline \multicolumn{10}{|c|}{ Total } & $100 \%$ \\
\hline
\end{tabular}

\section{SIMPULAN DAN SARAN}

Berdasarkan hasil analisis data dan pengujian hipotesis statistik dalam penelitian ini terhadap semua konsumen hotel yang menginap di Garden Permata Hotel Bandung. dengan jumlah responden sebanyak 100 tamu, maka dapat disimpulkan bahwa bauran pemasaran (marketing mix) yang dilakukan oleh Garden Permata Hotel Bandung yang terdiri dari product, price, place, promotion, people, process, dan phycical evidence secara bersama-sama maupun parsial berpengaruh terhadap keputusan konsumen menginap di Garden Permata Hotel Bandung Berdasarkan pada kesimpulan sesuai dengan hasil analisis data dan pengujian hipotesis statistik di atas, maka disarankan:

a. Diharapkan para personil Sales \& Marketing Garden Permata Hotel Bandung dapat meningkatkan kualitas dari berbagai program, anggaran dan prosedur yang menjadi bagian dari tahapan-tahapan implementasi bauran pemasaran (marketing mix) yang dilakukan oleh Sales \& Marketing dalam upaya pencapaian kinerja perusahaan. Guna semakin meningkatkan pencapaian kinerja perusahaan, maka para personil Sales \& Marketing sebaiknya semakin mengefektifkan bauran pemasaran (marketing mix)yang dijalankan sesuai dengan bidangnya.

b. Pencapaian kinerja perusahaan dalam hal ini banyaknya tamu yang menginap di Garden Permata Hotel Bandung merupakan hasil yang diraih secara langsung setelah implementasi bauran pemasaran (marketing mix), namun hasil tersebut sebaiknya perlu dilakukan evaluasi lebih lanjut untuk mengetahui beberapa hal yang perlu dibenahi dalam proses implementasi bauran pemasaran (marketing mix) perusahaan.

c. Diharapkan semua bagian/ departemen tersebut senantiasa meningkatkan kualitas koordinasi antar-bagian/ departemen guna menyukseskan pencapaian sasaran kinerja perusahaan sesuai dengan yang direncanakan sebelumnya.

d. Sehubungan dengan penentuan sasaran dalam bauran pemasaran/marketing mix perusahaan, maka upaya pemanfaatan pendekatan lain yang dapat dijadikan sebagai alternatif pertimbangan dalam mengukur pencapaian kinerja Garden Permata Hotel Bandung 


\section{DAFTAR PUSTAKA}

Akroush, M, N. (2011). The Infuence 7Ps Classification of the Service Marketing Mix on Performance Evidence from Jordan's Services Organisations. Jourdan: University of Jordan.

Buchari, A. (2009). Manajemen Pemasaran dan Pemasaran Jasa. Bandung: Alfabeta, IKAPI.

Danang, S. (2012). Dasar - Dasar Manajemen Pemasaran. Yogyakarta: CAPS.

Fandy, T. (2012). Service Management: Mewujudkan Layanan Prima Yogyakarta: ANDI.

Garden Permata Hotel Bandung. Annual Report 2012-2014. Bandung

Guilford, J.P. (1956). Foundamental Statistics in Physichology and Education. McGraw-Hill Inc. New York.

Hay’s, William L. (1969). Quantification in Psychology. Prentice Hall. New Delhi.

Kerlinger, F, N \& Elazar J, P. (1987). Foundation of Multiple Regression Analysis. Diterjemahkan oleh A. Taufik. Korelasi dan Analisis Regresi Ganda. Yogyakarta. Penerbit Nur Cahya.

Kotler, P., \& Armstrong, G. (2008). Prinsip - Prinsip Pemasaran Edisi Ke12.Jakarta: PT. Gelora Aksara Pratama, Erlangga.

Kotler, P., \& Keller, K. (2010). Manajemen Pemasaran Edisi Ketiga Belas Jilid 2. Jakarta: PT. Gelora Aksara Pratama, Erlangga.

Lovelock, C., \& H.Wirtz, J. (2011). Service Marketing: People Technology Strategy. New Jersey: Prentice Hall, Pearson Education Inc.

Mueller, D, J. (1986). Measuring Social Attitude: A Handbook for Researchers and Practioners. New York. Teacher College Press.

Nirwana, S, K, S. (1994). Analisis Jalur (Path Analysis). Unit Pelayanan Universitas Padjadjaran Bandung. Statistika Jurusan Statistika FMIPA

Peter, J. P. \& Olson, J, C. (2010). Consumer Behavior \& Marketing Strategy, Ninth Edition International Edition. New York: McGraw-Hill Irwin.

Singgih, S. (2003), "Statistik Deskriptif : Konsep dan Aplikasi dengan Microsoft Excel dan SPSS", Yogyakarta, ANDI. 
Sugiyono. (2011). Metode Penelitian Kuantitatif Kualitatif dan R\&D. Bandung: Alfabeta,IKAPI.

PHRI. (2015). Daftar Hotel Bintang 4 di Kota Bandung

UU Pariwisata No. 10 Tahun 2009

Pungnirund, B. (2013). The Influence of Marketing Mix on Customer Purchasing Behavior at Chatuchak Plaza Market. Bangkok: World Academy of Science, Engineering and Technology.

Yasanallah, P,. Vahid, B. (2012). Studying The Status of Marketing Mix (7P) in Consumer Cooperatives at Ilam Province from Members Perspectives.

Teheran:University of Ilam. 